\title{
Beşinci ve Altıncı Kondratieff Dalgalarının Teknolojik ve Sosyoekonomik Etkileri
}

\section{Technological and Socio-Economic Effects of Fifth and Sixth Kondratieff Waves}

\author{
Furkan BÖRÜ1 ${ }^{1}$, Dündar Murat DEMIRÖZ² $\odot$
}

\section{Öz}

Sanayi Devrimi'nden sonra, kapitalist ekonomiler hızlı büyümeye sürecine girmişlerdir. Fakat bu büyüme süreci dengeli değildir. Hızlı genişleme dönemlerini genellikle, sosyal refahın düşmesine ve yoksulluğa neden olan kriz dönemleri takip etmektedir. Takriben elli yıl süren Kondratieff Dalgaları, bu dalgalı gelişim sürecini teknolojik gelişmeler ve yenilikler ile ilişkili olarak açıklamaktadırlar. Bu çalışmanın amacı, Kondratieff Dalgalarının yarattığı yapısal ve kurumsal dönüşümleri açıklamak; bu çerçevede beklenen Altıncı Kondratieff Dalgası'nın yaratacağı etkileri incelemektir. Bu amaçla Carlota Perez tarafından ortaya konulan büyük gelişme dalgası yaklaşımı kullanılmıştır. Altıncı Kondratieff Dalgası'nın başlamasının, işsizlik, gelir dağılımı bozukluğu ve finans sektörü ile sanayi sektörü arasında bulunan bağların kopması sorunlarını derinleştireceği öngörüsü, çalışmanın ulaştığı en önemli sonuçtur. İçinde bulunduğumuz süreçte ve gelecek dönemde, bilgi teknolojilerinin etkilerinin gelişmekte olan ülkelerde daha çok hissedilmesi beklenmektedir. Bu durumun gelişmekte olan ülkelerde Beşinci Kondratieff Dalgası'nı başlatması olasıdır. Gelişmekte olan ülkelerde Beşinci Kondratieff Dalgası'nın başlaması; işsizlik, gelir dağıımı bozukluğu ve finans sektörü ile sanayi sektörü arasında bulunan bağların kopması gibi sorunları gündeme getirebilir. Mevcut durumda birçok gelişmekte olan ülkede bu sorunlar mevcuttur. Bu nedenle Beşinci Kondratieff Dalgası'nın başlaması, mevcut olan sorunları daha da ağırlaştıracaktır. Bu öngörü, çalışmanın ulaştığı diğer bir önemli sonuçtur.

Anahtar kelimeler: Uzun Dalgalar, Yapısal Dönüşüm, Yenilik JEL Sınıflaması: 032, N10, O14

\section{ABSTRACT}

After the industrial revolution, capitalist economies have entered the process of rapid growth. But this growth process is not steady.
'Dr., Türkiye Vakıflar Bankası T.A.O., Saray Mahallesi Dr. Adnan Büyükdeniz Caddesi No: 7/A-B, Umraniye, Istanbul, Turkey ${ }^{2}$ Prof. Dr. , Istanbul University, Faculty of Economics, Department of Economic Development and International Economics, Istanbul, Turkey

ORCID: H.A. 0000-0001-9239-1341; 0000-0003-1783-9905

\section{Corresponding author/Sorumlu yazar: Furkan BÖRÜ, \\ Türkiye Vakıflar Bankası T.A.O., Saray Mahallesi Dr. Adnan Büyükdeniz Caddesi No: 7/A-B, Ümraniye, İstanbul, Türkiye \\ E-mail/E-posta: furkan.boru@vakifbank.com.tr}

Submitted/Başvuru: 26.10.2018

Revision Requested/Revizyon Talebi: 21.05.2019

Last Revision Received/Son Revizyon: 26.10.2019

Accepted/Kabul: 08.11.2019

Citation/Atıf: Boru, F., Demiroz, D. M. (2019) Beşinci ve altıncı kondratieff dalgalarııın teknolojik ve sosyoekonomik etkileri. İstanbul iktisat Dergisi - Istanbul Journal of Economics, 69(2), 247-283.

https://doi.org/10.26650/ISTJECON2018-0006 
Rapid expansion periods are usually followed by crisis periods which cause social welfare to fall and poverty. The Kondratieff waves, which lasted for about 50 years, explain this fluctuating development process in relation to technological developments. The aim of this work is to explain the structural and institutional transformations created by the Kondratieff waves; to examine the effects of the expected sixth wave. For this purpose, the great surge of development approach introduced by Carlota Perez is used. The most important outcome of this study is the foresight that the beginning of the sixth Kondratieff wave will deepen the problems of unemployment, income distribution inequality and the breakdown of interrelation between finance and production. It is expected that the impacts of information technologies will be felt more in developing countries, today and in near future. This situation is likely to trigger start of fifth Kondratieff wave in developing countries that may raise aforementoned problems already existing in many developing countries. Therefore, the onset of the fifth wave will aggravate existing problems. This prediction is another result of the article.

Keywords: Long Waves, Structural Change, Innovation

JEL Classification: 032, N10, O14

\section{EXTENDED ABSTRACT}

After the industrial revolution, capitalist economies have entered the process of rapid growth. But this growth process is not steady. Rapid expansion periods are usually followed by crisis periods which cause social welfare to fall and poverty. This process of fluctuating development, which the capitalist development process has shown, was first examined in detail by the Russian economist Nikolai Kondratieff. Although Kondratieff made a detailed analysis in his work; he did not developed a theory that would explain these fluctuations. Joseph Schumpeter explained the reason for the formation of these long waves as innovations with the theory of the business cycle that he developed. According to Schumpeter, the volatile growth process of capitalist economies is caused by the emergence of new products, new services, and new processes.

Schumpeter was not able to elaborate two points in his business cycle theory. The first point concerns with the role of financial institutions in the development of long waves. The second point relates to the changes that long waves make to socio-economic structures and institutions. Carlota Perez tried to elaborate these two points by using approach of the great surges of development which she developed. According to Perez, the technology revolutions causes the great surges of devolepment which lasts for 50 or 60 years. Technology revolutions are accompanied by the creation of a new techno-economic paradigm. The great surges of development is divided into two periods, which are called installation 
period and deployment period. Moreover there is a transition phase between these two periods.

In the installation period that followed the technology revolution, new technologies and the new techno-economic paradigm rapidly spreads to all layers of the society. As a result, the structures and organizations established in the society are shaken. Problems such as unemployment, income distribution inequality, and the breakdown of interrelation between finance and production appear at this period. The installation period ends with financial crises which are caused by rapid increase in asset prices. In the period following the financial meltdown, the economy enters the recession phase of which the duration is uncertain. In this transitional period, the social tensions that arose in installation period become more visible due to the continuing stagnation. Therefore, the need for institutional reforms increases, especially in financial institutions. With the start of institutional reforms, deployment period of great surges of development begins. At this stage, the new techno-economic paradigm goes beyond the economy and spreads to all areas of the society. As a result of institutional reforms, problems such as unemployment, the breakdown of interrelation between finance and production, income distribution inequality are resolved. The great surges of development ends with the saturation of the technologies whose rise had caused it to begin. This process restarts with the emergence of a new technology revolution.

Innovations that took place in the field of information technology in the 1970s caused the fifth Kondratieff wave to start in the United States. The technology revolution in the field of information technology was accompanied by the spread of the effects of the new techno-economic paradigm to all layers of the society. The beginning of the fifth wave caused problems such as income distribution inequality, unemployment, and the breakdown of ties between finance and production in developed countries. These problems, were clearly observed in the United States, where the technology revolution in the field of information techology took place. The global financial crisis, which began in the United States in 2008, points to the end of the installation period of fifth wave. Because the 
effects of the changes created by information technologies were started to be felt in all layers of society, the deployment period of the fifth wave has begun in developed countries, especially in the USA. But aforementioned problems of installation period are still continuing.

It is quite possible that in 2020 and after wards, the technology revolution, which is expected to result in the progresses of nanotechnology and biotechnology, will start the installation period. The beginning of the sixth Kondratieff wave can bring back the problems which were seen in previous installation period. The continuing of these problems in developing countries may lead to the further aggravation of these problems with the onset of the sixth wave in the near future.

At the end of the installation periods of great surges of development, technologies, which started the technology revolution, saturated in the countries where technology revolution began. At the same time, saturated techologies transfered to the devoloping countries. Because of this situation, it is possible that effect of IT techologies in devoloping countries will be felt more in near future. On the other hand, the beginning of fifth wave in devoloping countries can cause problems which are seen in the installation period. Currently, many devoloping countries faces these problems. So new technologies can deepen their effect. 


\section{Giriş}

Bugünün gelişmiş, hatta gelişmekte olan ekonomileri de dâhil olmak üzere, ülkelerin kişi başına düşen milli gelirleri uzun dönemde devamlı olarak artmaktadır. Günümüz ekonomilerinde, kişi başına düşen milli gelir rakamlarında sağlanan kalıcı artışlara rağmen; bundan yaklaşık üç yüz yıl önce aynı durum söz konusu değildi. En güçlü imparatorluklar da dâhil olmak üzere, ülkelerin yaşam standartları hemen hemen eşitti ve üstelik çok fazla değişmiyordu (Lucas, 2004, s. 1). Fakat bu durum, bin sekiz yüz yılı öncesi dönemde, teknolojik değişimlerin olmaması veya bu değişimlerin üretime yansımaması anlamına gelmemektedir (Clark, 2013, s. 31). Bin sekiz yüz yılı öncesi toplumlarda da kayda değer teknolojik gelişmeler olmuştu; fakat bu değişimler, yaşam standartlarında iyileşmeye değil, nüfus artışına sebebiyet vermişti (Lucas, 2004, s. 3).

İngiltere'de on sekizinci yüzyılın son çeyreğinde başlayan ve on dokuzuncu yüzyılda da devam eden Sanayi Devrimi, teknolojik değişim ile yaşam standartları arasındaki ilişkinin değişmesine neden olmuştur. Sanayi Devrimi ve sonrasında meydana gelen teknolojik ilerlemeler; kişi başına düşen milli gelir seviyesi ve bilgi birikiminin eş zamanlı olarak, kalıcı bir şekilde artmasına sebep olmuştur. Bu durum, yaşam standartlarının teknolojik gelişmeler ile birlikte kalıcı olarak artması sonucunu doğurmuştur (Landes, 2017, s. 198).

On dokuzuncu ve yirminci yüzyıllarda İngiltere ile benzer kurumları benimseyen, bilim ve teknoloji alanında hızlı gelişmeler sağlayan ülkeler de, kişi başına düşen milli gelir düzeylerini hızla artırmışlar, hızla sanayileşmeye başlamışlardır. Dolayısıyla dünya ekonomisi, Sanayi Devrimi'ni takip eden dönemde, daha önce eşi benzeri görülmemiş büyüme oranlarını yakalamıştır.

Kapitalist ekonomiler, Sanayi Devrimi sonrasındaki dönemde yüksek büyüme oranlarına ulaşmalarına rağmen; milli gelir düzeylerinde meydana gelen yıllık değişimler, her zaman doğrusal bir büyüme eğilimi izlememiştir. Bu durumun sonucu olarak, hızlı büyüme dönemleri kadar daralma dönemleri de kapitalist ekonomilerin gelişme sürecinde görülmektedir. Özellikle elli yıl süren uzun dalgalar, kapitalist 
ekonomilerin uzun dönemli olarak gösterdiği dalgalı büyüme sürecini açıklamakta oldukça önemlidir. Elli yıl süreli uzun dalgalar, ilk defa Kondratieff tarafından ayrıntılı olarak gözlenmiş, daha sonra Schumpeter tarafından detaylı olarak açıklanmışır.

Bu çalışmanın amacı, genelde elli yıl süren ve Kondratieff Dalgası olarak adlandırılan uzun dalgaların yarattığı sosyoekonomik ve kurumsal dönüşümleri açıklamak; bu çerçevede Beşinci Kondratieff Dalgası'nın ve beklenen Altıncı Kondratieff Dalgası'nın yaratacağı etkileri incelemektir. Bu çalışmanın daha önce yapılan benzer çalışmalardan en önemli farkı, Kondratieff Dalgalarının yaratacağı kurumsal ve sosyoekonomik dönüşümleri, Carlota Perez tarafından ortaya konulan büyük gelişme dalgası yaklaşımını kullanarak, daha detaylı incelemesidir. Daha önce Hirooka (2006) ve Nefiodow ve Nefiodow (2014) tarafından yapılan çalışmalar daha çok bir sonraki Kondratieff Dalgası'na eşlik edecek teknolojik yeniliklere odaklanırken; bu çalışma, gelecek Kondratieff Dalgası'nın yaratacağı kurumsal ve sosyoekonomik değişimleri daha çok vurgulamaktadır.

Çalışmanın ilk bölümünde, uzun dalgaların yarattığı kurumsal ve sosyoekonomik dönüşümleri detaylı olarak inceleyen Carlota Perez'in görüşleri açılanacaktır. İkinci bölümde, Beşinci Kondratieff Dalgası'nın neden olduğu dönüşümlerden bahsedilecektir. Üçüncü bölümde, beklenen Altıncı Kondratieff Dalgası'ndan bahsedilecek; yaratacağı olası sosyoekonomik ve kurumsal dönüşümler açıklanmaya çalışılacaktır. Sonuç bölümünde ise, ulaşılan sonuçlar ve çalışmada bulunan önemli noktalar özetlenecektir.

\section{Uzun Dalgaların Kurumsal ve Sosyoekonomik Değişimlere Etkileri}

Schumpeter'in ve Kondratieff'in çalışmaları, uzun dalga teorisinin gelişmesinde merkezi rol oynamıştır (Silverberg, 2007, s. 800). Schumpeter, uzun dalgalar ile yenilikler arasındaki ilişkinin mekanizmasını ortaya koyan ilk iktisatçıdır (Silverberg ve Verspagen, 2003, s. 671). Kondratieff'in ise ekonometrinin öncülerinden biri olduğu rahatlıkla kabul edilebilir. Kondratieff, uzun dalgaların varlığını iktisadi değişkenlere ait zaman serilerinden çıkartmaya çalışmışır (Rosenberg ve Frischtak, 1984, s. 7); fakat bir teori ortaya koyamamıştır. 
Uzun dalgalar teorisinin gelişimine yaptıkları bu çok önemli katkılara rağmen; iki iktisatçı da çalışmalarını yayınladıkları tarihlerden itibaren eleştirilere maruz kalmıştır. Özellikle Schumpeter tarafından geliştirilen uzun dalga teorisi, Simon Kuznets tarafından üç noktada yetersiz bulunmuştur. Illk eleştiri yeniliklerin ekonomiye etkisi ile ilgilidir. Yeniliklerin ekonominin tamamında etki yaratabilmesi için çok büyük olmaları veya bir araya gelmeleri gerekmektedir. Kuznets, Schumpeter'in büyük yenilikler veya yeniliklerin bir araya gelmesi konusunda yeterince kanıt sunamadığııı iddia etmektedir. Kuznets'in Schumpeter'e yönelttiği ikinci eleştiri, yeniliklerin ekonomiye etki süresi ile ilgilidir. Kuznets'e göre yeniliklerin ekonomiye etkisi on yıllar sürmemektedir. Dolayısıyla yenilik patlamaları uzun dalgalara değil, kısa dönemli iş çevrimlere neden olmaktadır. Kuznets'in üçüncü eleştirisi depresyon ve daralma dönemleri ile ilgilidir. Yenilikler, etkileri on yıllar süren genişleme dönemleri yaratıyorsa neden buhran dönemleri meydana gelmektedir? Kuznets, Schumpter'in buhran dönemlerinin varlı̆ıını yeterince açıklayamadığını ileri sürmektedir (Freeman, 1987, s. 297).

Schumpeter'in ortaya koyduğu uzun dalga modeline Kuznets'in vurguladığı noktalar dışında da eleştiriler yöneltilmiştir. Bu eleştirilerden biri, Schumpeter'in uzun dalga modelinde, teknolojik değişimin sosyoekonomik yapılarda ve kurumlarda yarattığı dönüşümlere yeterince yer vermemesidir (Perez, 2002, s. 23). Bu nedenle, Schumpeter, organizasyon yapılarında meydana gelen değişimler ile teknik yenilikler arasındaki ilişkinin önemine işaret etmesine rağmen; hem teknoloji alanındaki, hem de ekonomi alanındaki paradigma değişimi düşüncesi ortaya koyamamıştır (Freeman, 1987, s. 305).

Kuznets tarafından Schumpeter'e yönetilen eleştirilerin zamanı için (bin dokuz yüz kırklı yıllar) oldukça gerçekçi olduğu rahatlıkla iddia edilebilmektedir (Kleinknecht ve Panne, 2006, s. 119). Bu durum birçok yazarı, bin dokuz yüz seksenli yıllardan itibaren, hem Kuznets tarafından, hem de diğer iktisatçlar tarafından yönetilen eleştirileri karşılamaya yönelik çalışmalar yapmaya sevk etmiştir. İktisat teorisi alanında yapılan yeni araştırmalar ve ortaya çıkan yeni yaklaşımlar, Schumpeter'in uzun dalga teorisinin yeniden değerlendirilmesinde etkili olmuşlardır. Bu yaklaşımlardan biri, Aghion ve Howitt tarafından ortaya konulan ve Schumpeter'in fikirlerini temel alan büyüme modelidir. 
Agion ve Howitt tarafından ortaya konulan büyüme modelinin temelinde, içsel büyüme modelleri bulunmaktadır. Agion ve Howitt, içsel büyüme modeline Schumpeter tarafından açıklanan yaratıcı yıkım sürecini eklemişlerdir. Modelde, ekonomik büyümenin temelinde teknolojik ilerlemeler bulunmaktadır. Teknolojik ilerlemelerin kaynağı ise, yeniliklerdir. Yenilikler, firmaların üretim sürecinde kullandıkları ara mallardır. Firmalar, başarılı yeniliklerinin patentlerini aldıkları durumlarda tekel karları elde etmektedirler. Bu durum, firmaların araştırma geliştirme faaliyetlerine yatırım yapmalarının temel nedenidir (Aghion ve Howitt, 1992, s. 349).

Genel denge yaklaşımının büyüme teorisine uygulanması olan Agion ve Howitt modelinin, Schumpeter'in fikirlerinin yeterli açıklamasını sunduğu tartışmalıdır (Silverberg, 2007, s. 810). Agion ve Howitt'in Schumpeter'in yaratıcı yıkım sürecini genel denge teorisi çerçevesinde ele alması, Schumpeter'in kapitalist ekonomilerin doğasının dengesiz olduğu ile ilgili fikirleri ile çelişmektedir. Bunun yanında modelde, teknolojinin ara mal olarak nitelendirilmesi, teknolojik değişim ile kurumsal ve sosyoekonomik değişimler arasındaki ilişkinin yeterince açıklanmamasına neden olmaktadır. Dolayısıyla teknolojik değişimin yarattığı siyasi, kültürel, sosyoekonomik değişimler, Agion ve Howitt tarafından ortaya konulan modelde yer almamaktadır.

Schumpeter'in ortaya koyduğu uzun dalga modelinde yeterince aydınlatamadığı bir diğer konu, yukarıda da ifade edildiği gibi sosyoekonomi ve teknoloji alanlarında meydana gelen paradigma değişimleridir. Bu boşluğu kapatmaya yönelik önemli çalışmalardan biri Giovanni Dosi tarafından yapılmıştır. Dosi, teknoloji paradigmasını terimini, Thomas Kuhn tarafından ortaya konulan bilimsel paradigma terimi ile benzer biçimde kullanmaktadır (Dosi ve Nelson, 2010, s. 66). Bilimsel paradigma, belli bir bilimsel araştırma alanının problemlerini, araştırma yöntemlerini, bu araştırma alanında cevaplanması gereken soruları belirlemektedir (Dosi, 1982, s. 152).

Bilimsel paradigma ile benzer yapıya sahip olan teknoloji paradigması kavramı, üç noktaya dayanmaktadır. Illk olarak teknoloji paradigması, belli hedefleri 
başarmak amacında olan belirli süreçleri ve bu süreçler ile ilişkili olan girdileri içermektedir. İkinci olarak, istenen ürünlerin tasarımda, farklı ve yeni fikirleri ifade etmektedir. Son olarak ise, ilgili alanlarda çalışan mühendisler, girişimciler ve tüketiciler için belli bir antlaşma kalıbı sunmaktadır. Benzer alanlarda çalışan kişiler, teknoloji paradigmasının yarattığı ortak dil ile birbirlerini anlayabilmektedirler (Dosi ve Nelson, 2013, s. 5). Teknoloji paradigması, bu özellikleri ile teknolojik bilginin yapısını ve nasıl oluştuğunu açıklamaya çalışmaktadır (Dosi ve Labini, 2007, s. 334).

Teknolojik değişimin yönünü açıklayan teknoloji paradigması (Dosi, 1982, s. 152), seçilmiş teknoekonomi problemlerine doğa bilimlerinden çıkarılan kurallar sayesinde belli çözüm reçeteleri sunmaktadır (Dosi ve Nelson, 2010, s. 66). Bu çözüm reçetelerinin önemli parçası, süreçlerin ve ürünlerin nasıl düzenleneceğini belirleyen tasarım şekilleridir. Her teknoloji paradigmasında, ürünler arasında bulunan benzerlikleri sağlayan hâkim tasarım şekilleri bulunmasa da; teknoloji ile ilgili alanlarda çalışanlar tarafından paylaşılan ortak bilgi tabanı ve araştırmacılar tarafından problemlerin çözümü için kabul edilen deneysel araştırma yöntemleri bulunmaktadır (Dosi ve Nelson, 2013, s. 6).

Teknoloji paradigması, yukarıda ifade edilen özellikleri sayesinde, belli bir araştırma alanında en iyi harekete engel oluşturan kısıtları tanımlamakta; bu kısıtları aşacak çözüm yöntemlerini sunmaktadır (Dosi ve Nelson, 2010, s. 67). Dolayısıyla teknoloji paradigması, belli bir alanda çalışanları, o alanda ne yapılabileceği konusunda yönlendirmektedir. Bu çerçevede performansı değerlendirmek için de ölçütler sağlamakta; dolayısıyla neyin neden daha iyi olduğunu da açıklamaktadır (Dosi ve Nelson, 2013, s. 6). Teknoloji paradigması, neyin daha iyi olduğunu açıklaması nedeniyle dışlayıcı etkiye sahiptir. Mühendislerin ve araştırmacıların hayal gücü, teknoloji paradigması tarafından şekillenmektedir. Mevcut teknoloji paradigmasına uymayan teknolojik olanaklar, araştırmacılar tarafından dikkate alınmamakta, görmezden gelinmektedir (Dosi, 1982, s. 153).

Giovanni Dosi, geliştirdiği teknoloji paradigması kavramı ile teknolojik gelişmenin çerçevesini ve teknolojik gelişmenin neden belli bir yol boyunca 
ilerlediğini açıklamaktadır. Dolayısıyla Dosi, Schumpeter'de bulunmayan teknoloji paradigması kavramını tanımlamaktadır; fakat teknolojik değişimin ağırlıklı olarak mühendislik yönüne ve teknik özelliklerine odaklanmaktadır. Teknolojik değişim, sadece ürünlerin ve süreçlerin teknik özelliklerinde değişime neden olmamakta; toplumun bütün alanlarında dönüşümlere yol açmaktadır (Freeman ve Perez, 1988, s. 47). Corlota Perez tarafından geliştirilen teknoekonomi paradigması kavramı, Dosi tarafından detaylı olarak açıklanmayan teknolojik değişimlerin ekonomik, kurumsal, kültürel alanlarda yarattığı etkilere odaklanmaktadır.

Teknoloji devrimleri, Perez'in teknoekonomi paradigması kavramını açılarken temel çıkış noktasıdır. Teknoloji devrimi, ekonominin tamamında yükselişe neden olan yeni endüstrilerin, ürünlerin ve hizmetlerin kümesi olarak ifade edilebilmektedir (Papenhausen, 2008, s. 789). Yeni ürünlerin, hizmetlerin ve süreçlerin birbirleri ile yakından bağlantılı olması (Lauça, 2007, s. 769) ve kümelenmesi, teknoloji devrimine yol açan temel faktördür. Küme oluşturan bu yenilikler, toplumun bütün alanlarında dönüşümlerin yolunu açmaktadırlar (Hirooka, 2005, s. 304). Bu nedenle teknoloji devrimleri, yeni teknoekonomi paradigmalarının oluşmasına neden olmaktadır (Perez, 2009a, s. 11).

Yeni teknoloji kümelerine eşlik eden teknoekonomi paradigmaları, üretken organizasyonların ideal tipini veya teknoloji konusunda hâkim olan ortak sağduyuyu ifade etmektedirler (Perez, 1983, s. 361). Teknoekonomi paradigmaları, ekonomideki göreceli maliyet yapılarının belirlenmesinde, organizasyonlar ile ilgili ölçütlerin ve ilkelerin oluşmasında, yeniliklerin yayılabileceği alanların sınırlarının belirlenmesinde etkili olmaktadırlar (Perez, 2009a, s. 14).

Ortaya çıkan yeni teknoekonomi paradigmasının yarattığı en önemli etkilerden biri de, bu yeni paradigmanın tasarımcılar, mühendisler ve yöneticiler arasında hâkim olan ve eski teknoekonomi paradigmasından kaynaklanan ortak yaklaşımları ve sağduyuyu değiştirmesidir. Belirli endüstilerde başlayan teknoekonomi paradigması değişimi, daha sonra ekonominin tamamınında etkili olmaktadır (Freeman, 1994, s. 487). Yeni teknoekonomi paradigması ile oluşan yeni sağduyu, yatırımcılara ve mühendislere yeni teknolojilerin potansiyelini ve gelişebilecekleri 
yolları göstermektedir (Perez, 2009a, s. 15). Dolayısıyla yeni teknoekonomi paradigması, yenilik ve yatırım ile ilgili davranışları etkilemekte; yeni tasarımlar, ürünler ve kâr firsatları için rehberlik etmektedir (Perez, 2002, s. 16).

Teknoekonomi paradigmalarının yarattığı bir diğer önemli etki, ekonomideki göreceli maliyet yapılarını değiştirmeleridir. Ürünlerin ve üretim faktörlerinin maliyetlerini düşüren anahtar faktör olarak adlandırılan girdiler, bu duruma neden olmaktadırlar (Perez, 1985, s. 444). Yeni anahtar faktörün görünür hale gelebilmesi için hâkim teknoekonomi paradigmasına eşlik eden mevcut anahtar faktörün yetersizliklerinin iktisadi aktörler tarafından algılanması gerekmektedir. Bu nedenle yeni anahtar faktörün ortaya çıkışı, yeni teknoekonomi paradigmasının yerleşmesinde ve oluşumunda önemli rol oynamaktadır (Perez, 1983, s. 361-362). Dördüncü teknoloji devriminin anahtar faktörü olan petrol, o dönemde ortaya çıkan yeni ürünlerin göreceli maliyetlerinin azalmasında önemli rol oynamış; uçaklar ve otomobiller gibi Dördüncü Kondratieff Dalgası'nın önemli ürünlerinin yaygın olarak kullanılmasına katkı yapmıştır.

Organizasyon yapıları, yeni teknoekonomi paradigmasının etkilediği diğer bir önemli alandır. Yeni teknolojiler, çalışma şekillerinin ve tüketim kalıplarının değişmesine neden olmaktadırlar (Perez, 2009a, s. 16). Firmaların mevcut organizasyon yapıları, bu durumun sonucu olarak, yetersiz kalmaktadırlar. Dolayısıyla yeni teknolojilerin ortaya çıkması, yeni firma organizasyonlarının ve yönetim şekillerinin oluşmasına neden olmaktadır. Ortaya çıkan yeni yönetim kalıpları ve organizasyon şekilleri, yeni teknoekonomi paradigmasının oluşmasına önemli katkı yapmaktadırlar (Perez, 1985, s. 444).

Perez, teknoloji devrimi ile başlayan ve teknoekonomi paradigmasınının yayılması ile iktisadi alanın çok ötesinde etkiler yaratan süreci, büyük gelişme dalgası olarak adlandırmaktadır. Kırk ile altımıs yıl arasında süren büyük gelişme dalgası, Schumpeter tarafından açıklanan Kondratieff Dalgaları'ndan farklı içeriğe sahiptir. Schumpeter, uzun dalgaları milli gelir serilerinde gözlemlediği hareketlere bağılı olarak açıklamakta; teknolojik devrimlerin yarattığı ekonomik sonuçlara odaklanmaktadır. Perez tarafından ortaya konulan büyük gelişme dalgası ise, 
teknoloji devrimlerinin yarattığı toplumsal dönüşümleri de açıklamayı amaçlamaktadır (Perez, 2007, s. 783).

Büyük gelişme dalgası, kuruluş safhası ve yayılma safhası olarak adlandırılan iki evreye ayrılmaktadır. Bu iki evre arasında ise geçiş safhası bulunmaktadır. Geçiş safhası, kuruluş evresinin sonunda ortaya çıkan finansal krizin ardından oluşan durgunluk süreci ile ayırt edilmektedir (Perez, 2014, s. 21).

Büyük gelişme dalgasının kuruluş safhası, teknoloji devrimi ile başlamakta, yirmi veya otuz yıl sürmektedir (Perez, 2007, s. 784). Yeni tasarımlar ve yeni ürünler, teknoloji devrimi ile birlikte ortaya çıkmaktadırlar. Bu durum, genç girişimciler için yeni firsatlar sunmaktadır (Perez, 2002, s. 49). Fakat yeni teknolojilerin yayılması kolay bir süreç değildir. Yeni teknolojileri kârlı yatırımlara dönüştürmek isteyen girişimciler, eski teknoekonomi paradigmasının direncini kırmak zorundadırlar. Eski teknoekonomi paradigması bu safhanın başında hala güçlü konumda olmasına rağmen (Perez, 2007, s. 784); bu para digmaya bağlı endüstriler zor durumdadırlar. Doymuş pazarlar ile karşı karşıya kalan bu endüstriler, kârlarında meydana gelen düşüşlere çözüm aramaktadırlar (Perez, 2002, s. 49).

Yeni ortaya çıkan teknolojiler, pazarların bu doymuşluğuna çözüm getirmekte, üretkenlik artışlarına neden olmaktadırlar. Yeni teknolojiler aynı zamanda, eski paradigmaya dayalı endüstrilere yatırım yapmak istemeyen ve ellerinde birikmiş fonlar bulunan yatırımcılara kârlı firsatlar sunmaktadırlar (Perez, 2009b, s. 789). Dolayısıyla yeni teknolojiler, eski teknoekonomi paradigmasına bağlı olan endüstrilerin pazar paylarının hızla düştüğü bu evrede, hızla yayılmaktadır. Yeni teknolojilerin yayılmasına, yeni teknoekonomi paradigmasının iş dünyasının her alanına hızla nüfuz etmesi eşlik etmektedir. Bu durum, yeni tasarım şekillerinin ve yeni sağduyunun ekonomide yavaş yavaş hâkim olması sonucunu doğurmaktadır. Yeni teknolojilerin olanaklarından faydalanmak isteyen yeni firmalar ortaya çıkmaktadır. Bu firmalar, eski teknolojilere bağlı endüstrileri finanse etmek istemeyen finansal kurumların varlığından dolayı, yatırımlarına daha rahat finansal kaynak bulabilmektedirler. Bu dönemde ortaya çıkan yeni altyapılar, yeni teknolojilerin kullanımı kolaylaştırmaktadırlar (Perez, 2014, s. 21). 
Yeni teknolojilerin yayılması, firmalar için yeni olanaklar yaratmasına rağmen; olumsuz sonuçlara da neden olmaktadır. Ekonomik durgunluk, yeni teknolojileri kullanan endüstrilerin hızlı yayılması, firmaların üretim süreçlerini yeni şartlara uygun hale getirme çabaları gibi faktörler, kuruluş safhasında işsizlik oranlarının yüksek olmasına neden olmaktadır (Perez, 2002, s. 49).

Bozulan gelir dağılımı, yeni teknolojilerin yayılmasının yarattığı bir diğer olumsuz etkidir. Artan işsizlik, gelir dağılımının bozulmasına neden olan faktörlerin başında gelmektedir. Gelir dağılımının bozulmasına neden olan diğer faktörler, finansal manipülasyonlar ve finansal varlıkların fiyatlarında görülen hızlı artışlardır (Perez, 2014, s. 22). Finansal varlıkların fiyatlarında meydana gelen artışlarından ve finansal manipülasyonlardan yararlananlar, kuruluş safhasında hızla zenginleşirken; işsizlik artışı toplumun büyük çoğunluğunu fakirleştirmektedir. Bu durum, gelir dağılımının bozulmasına neden olmaktadır (Perez, 2002, s. 50-51).

Kuruluş safhasında ortaya çıkan bir diğer olumsuz etki, finans sektörünün sanayi sektöründen kopmasıdır. Sermaye sahipleri ve girişimciler, finansal kurumların ekonomide artan etkisi ile beraber sermaye piyasalarında daha çok işlem gerçekleştirmektedirler. Bu durum, yeni teknolojilere ve altyapılara yapılan yatırımların hızla artmasına neden olmaktadır Bu hızlı yatırım artışı, finansal varlıkların fiyatlarının aşırı değerlenmesi sonucunu doğurmaktadır (Perez, 2009b, s. 783-784). Finansal varlıkların fiyatlarının aşıı değerlenmesi, tasarruf sahiplerinin ve finansal kurumların, finansal varlıklara daha fazla yatırım yapmasına neden olmaktadır. Bu süreç, üretim yapan firmaların faaliyetlerini ve yatırımlarını sürdürebilmeleri için gerekli olan fonlara ulaşımını zorlaştırmaktadır.

Tam rekabet, piyasalarda, kuruluş safhasının başlarında görülmektedir. Fakat oligopolistik yapı, yeni teknolojiler ve yeni teknoekonomi paradigması yayıldıkça, piyasayalara hâkim olmaktadır (Perez, 2002, s. 51). Dolayısıyla kuruluş safhasının sonunda, ekonomide büyük firmalar görülmeye başlamakta, yeni teknoekonomi paradigması eski teknoekonomi paradigmasına karşı üstünlük sağlamakta, finansal varlıkların fiyatları aşırı değerlenmektedir (Perez, 2010, s. 6). 
Aşırı değerlenen finansal varlıkların fiyatlarının hızla değer kaybetmesi ve ardından gelen finansal çöküş, kuruluş safhasının bitişine işaret etmektedir. Ekonomi, finansal çöküş sonrası, süresi belirsiz olan durgunluk sürecine girmektedir. Durgunluk süreci, kuruluş safhasında ortaya çıkan sosyal gerilimlerin daha fazla görülür hale gelmesine sebep olmaktadır. Bu durum, toplumda huzursuzlukların daha çok artması sonucunu doğurmaktadır. Bu olumsuzluklar, ekonomik yapının değiştirilmesi yönünde baskıların çoğalmasına neden olmakta; finansal piyasaların düzenlenmesini gündeme getirmektedir (Perez, 2007, s. 785). Ekonomide ve toplumda reform ihtiyacı, yayılma safhasının başlamasına neden olmaktadır.

Büyük gelişme dalgasının ikinci evresi olan yayılma safhası, yirmi ile otuz yıl arası sürmektedir. Yeni teknoekonomi paradigması, yayılma safhasında tam egemenliğini kurmuş, toplumun bütün katmanlarına yerleşmiştir (Perez, 2007, s. 785). Yeni teknoekonomi paradigmasının etkisi, bu evrede sadece ekonomi ile sınırlı kalmamakta, kamu yönetimi, eğitim gibi alanlara da yayılmaktadır (Perez, 2002, s. 54). Kuruluş safhasında oluşan toplumsal gerilimleri ve ekonomik çarpıklıkları azaltmaya yönelik çabalar, yayılma safhasında oldukça belirgin hale gelmektedir (Perez, 2014, s. 22). Bu çerçevede, finansal piyasalara ve finansal kurumlara düzenlemeler getirilmekte, faaliyetlerini denetleyecek düzenleyici kurumlar oluşturulmaktadır (Perez, 2009b, s. 790). Bu durumun sonucu olarak, sanayi sektörü, ekonomide tekrar hâkim hale gelmekte ve yatırım kararlarını belirlemektedir (Perez, 2010, s. 6).

Kuruluş safhasında toplumsal gerilimlere neden olan işsizlik ve gelir dağılımı bozukluğu gibi sorunlara çözüm için; iş kanunları çalışanlar lehine düzenlenmekte, gelir düzeyleri düşük kesimlerin durumunu düzeltecek kurumlar oluşturulmaktadır. Böylece gelir dağılımı düzelmekte, orta sınıflar güçlenmekte, toplumun genelinde tüketim eğilimi artmaktadır (Perez, 2002, s. 54).

Ekonomide etkili büyümenin gerçekleşmesi için çok önemli rol oynayan kurumların (Nelson, 2008, s. 6), toplumun bütün alanlarda düzenleyici rolünü oynamaya başlaması, hızlı büyüme sürecini tetiklemektedir. Gelir dağılımının düzelmesi ile artan tüketim eğilimi ve ekonominin hızlı büyümesi için gerekli olan 
altyapıların kuruluşunun tamamlanması, büyüme sürecine destek olmaktadır. Bir önceki evrede ortaya çıkmaya başlayan büyük şirketler, yayılma safhasında büyüme sürecinin itici gücüdür.

Kurumsal değişimin etkisi ile tetiklenen hızlı büyüme süreci, pazarların ve mevcut teknolojilerin doygunluğa ulaşması ile sona ermektedir. Yayılma safhasının sonlarına doğru, teknolojiler olgunlaşmakta, şirketlerin üretkenlik düzeyleri ve kârları azalmaktadır. Dolayısıyla durgunluk eğilimi tekrar ortaya çıkmaktadır (Perez, 2002, s. 54-55). Bu durum, mevcut teknoekonomi paradigmasının etkinliğinin ve büyük gelişme dalgasının sonuna işaret etmektedir. Yeni teknoloji devrimi ile süreç tekrar başlayacaktır.

Büyük gelişme dalgası yaklaşımı, Schumpeter'in uzun dalga kuramında yeterince üzerinde durmadığı, uzun dalgaların toplumda ve kurumlarda meydana getirdiği değişimleri, detaylı olarak açıklamaya çalışmaktadır. Altıncı Kondratieff Dalgası'nın meydana getireceği olası değişimleri, büyük gelişme dalgası yaklaşımı ile tahmin etmeye çalışmak, önemli avantajlara sahiptir. Fakat bunu yaparken iki noktaya dikkat etmek gerekmektedir. Bu noktalardan ilki, modelin teorik yapısı ile ilgilidir. Her ne kadar model, daha önce gerçekleşen beş dalgada ortak olarak gözlemlenen olgulara dayansa da, her dalga kendi içinde diğer dalgalardan farklı özelliklere sahiptir. Bu farklılar, büyük gelişme dalgaları sırasında görülen tekil olaylardan ve dalgaların gelişiminin dayandığı farklı koşullardan kaynaklanmaktadır. Bu nedenlerden dolayı, uzun gelişme dalgalarının süreleri birbirinden farklı olabilmektedir (Perez, 2002, s. 57).

Büyük gelişme dalgaları yaklaşımı ile Altıncı Kondratieff Dalgası'nda meydana gelecek değişimleri tahmin etmeye çalışırken dikkat edilmesi gereken ikinci nokta, büyük gelişme dalgalarının zamanda ve mekânda yayılımı ile ilgilidir. Birinci ve ikinci dalgalar İngiltere'de; üçüncü, dördüncü ve beşinci dalgalar ise Amerika Birleşik Devletleri'nde başlamışlardır. Ortaya çıkan yeni teknolojiler, merkez ülkelerde doygunluğa ulaştıktan sonra çevre ülkelere yayılmışlardır (Perez, 2002, s. 65). Örneğin İngiltere'de Birinci Kondratieff Dalgası ile ortaya çıkan teknolojiler, Japonya'da yüz yıl sonra görülmeye başlamıştır. Bu nedenle Birinci Kondratieff 
Dalgası'nın etkisi, Japon ekonomisine ve toplumuna ortaya çıkışından çok sonra ulaşmışır (Hirooka, 2005, s. 298). Bu nedenle büyük gelişme dalgalarının bütün dünyada aynı anda görüldügünü iddia etmek zordur.

\section{Beşinci Kondratieff Dalgasının Yarattığı Sosyoekonomik ve Kurumsal Değişimler}

Sanayi Devrimi'nin İngiltere'de ortaya çıkışından bugüne beş tane Kondratieff Dalgası görülmüştür. Carlota Perez tarafından büyük gelişme dalgaları olarak da adlandırılan Kondratieff Dalgaları, aşağıda bulunan Tablo 1'de gösterilmektedir. Tablo 1'in ilk sütunu, Kondratieff Dalgası'nın başlama yılını ve ülkesini; ikinci sütunu Kondratieff Dalgası'nın itici sektörünü; üçüncü sütunu Kondratieff Dalgası sırasında meydana gelen krizin yılını ve gerçekleştiği ülkeyi göstermektedir (Perez, 2009b, s. 782). Tablo 1'de görüldüğü gibi bin dokuz yüz yetmiş bir yılında Amerika Birleşik Devletleri'nde başlayan Beşinci Kondratieff Dalgası, bin dokuz yüz doksanlı ve iki binli yıllarda özellikle bilgi teknolojileri alanında yeniliklerin ortaya çıkmasına neden olmuştur (Grinin ve Grinin, 2015a, s. 127).

Tablo 1: Kapitalist Gelişme Sürecinde Ortaya Çıkan Beş Kondratieff Dalgası

\begin{tabular}{|l|l|l|}
\hline Patlama Yılı ve Ülke & Büyük Gelişme Dalgası & Çöküş Yılı ve Ülke \\
\hline 1771 İngiltere & Endüstri Devrimi & 1793 İngiltere \\
\hline 1829 Büyük Britanya & Demir Yolu ve Buhar Çağı & 1847 Büyük Britanya \\
\hline $\begin{array}{l}1875 \text { Büyük Britanya, } \\
\text { Almanya, ABD }\end{array}$ & Demir ve Ağır Mühendislik Çağı & $\begin{array}{l}1890-1893 \text { Arjantin, } \\
\text { Avustralya ve Diğer Ülkeler }\end{array}$ \\
\hline 1908 ABD & $\begin{array}{l}\text { Otomobil, Petrol, } \\
\text { Petrokimyasallar Çağı }\end{array}$ & 1929 ABD \\
\hline 1971 ABD & Bilgi ve Dijital İletişim Çağı & $\begin{array}{l}2000 \text { ve } \\
2007-2008 \text { ABD }\end{array}$ \\
\hline
\end{tabular}

Kaynak: C. Perez, (2009b).

\subsection{Beşinci Kondratieff Dalgasının Teknoloji ve Organizasyon Yapılarında Yarattığı Değişimler}

Mikroelektronik, kişisel bilgisayarlar ve bilgi teknolojileri alanında meydana gelen yenilikler, Beşinci Kondratieff Dalgası'nın çekirdek teknolojilerini oluşturmaktadırlar (Akaev ve Rudskoi, 2017, s. 16). Bu yeni teknolojilerin ortaya 
çıkması; başta $A B D$ olmak üzere, gelişmiş kapitalist ülkelerde teknoloji devriminin başlamasına neden olmuştur. Özellikle bilgi teknolojileri alanında meydana gelen yenilikler, imalat teknolojileri, yazılım mühendisliği, tüketici elektroniği, ofis sistemleri, iletişim teknolojileri alanlarında ortaya çıkan yeni ürün, süreç ve organizasyonların oluşumunu derinden etkilemişlerdir. Beşinci Kondratieff Dalgası ile beraber ortaya çıkan değişimler, teknoloji alanı ile sınırlı kalmamış; sosyal yapıda ve kurumlarda köklü dönüşümlere yol açmışır (Nefiodow ve Nefiodow, 2014, s. 327-328). Bu duruma neden olan temel faktör, yeni teknoekonomi paradigmasının ortaya çımasıdır.

Telekomünikasyon ve internet altyapısının yaygınlık kazanması, Beşinci Kondratieff Dalgası ile birlikte ortaya çıkan yeni teknoekonomi paradigmasının ekonominin tamamında etkili olmasını sağlayan en önemli nedenlerden biridir. Bu durum, hem üreticilerin hem de tüketicilerin pazarlara ve bilgiye ulaşım maliyetlerinin azalmasına neden olmuştur (Freeman ve Perez, 1988, s. 61). Telekomünikasyon ile internet altyapılarının gelişmesi ve bilgiye ulaşım maliyetlerinin azalması, yeni teknoekonomi paradigmasının önemli özelliklerinden biri olan, anlık küresel iletişimin önünü açmıştır. Bu durumun sonucu olarak küreselleşme süreci, yeni teknoekonomi paradigmasının oluşmasında ve temel özelliklerinin belirlenmesinde önemli rol oynamıştır.

Bilgi ve iletişim teknolojilerinde meydana gelen yenilikler, firmaların üretim ve organizasyon yapılarında da önemli değişimlere yol açmışır. Yeni teknolojiler, esnek üretim ve esnek organizasyon yapılarının ortaya çıkmasına neden olmuş; içeriği değişen ürün ve hizmetlerin üretimini kolaylaştırmıştır (Freeman ve Perez, 1988, s. 61). Bu durum, yeni teknoekonomi paradigmasının önemli özelliklerinden biri olan, ürün çeşitliliğinin artmasına neden olmuştur. Ürün çeşitliliğinin artması ile birlikte piyasalarda segmantasyon da artmıştır (Perez, 2010, s. 5).

\subsection{Beşinci Kondratieff Dalgasının İş Piyasalarında Yarattığı Değişimler}

Beşinci Kondratieff Dalgası ile birlikte ortaya çıkan yeni teknoekonomi paradigması, iş piyasalarında önemli değişimlere neden olmuştur. Bilgi teknolojileri 
alanında meydana gelen yenilikler, iş piyasalarında orta seviye vasıflara sahip olan iş gücüne talebi azaltmış; düşük ve yüksek vasıflara sahip olan iş gücü ne talebi ise arttırmıştır (Freeman ve Perez, 1988, s. 61). Bu durum, yeni teknoekonomi paradigmasının önemli özellikleri olan, bilginin üretim ve hizmet süreçlerinde önemli bir girdi olarak kullanılması ve üretim ile hizmet süreçlerinin giderek daha fazla dijitalleşmesi ile yakından ilişkilidir. Üretim ve hizmet süreçlerinin dijitalleşmesi, kural ve algoritmaya dayalı işlerde istihdam olanaklarının azalmasına neden olmuştur. Bu durumun yarattığı en önemli etki, orta seviye vasıflara sahip iş gücüne ihtiyaç duyan mesleklerin azalmasıdır (Brynjolfsson ve Mcafee, 2014, s. 28). Buna karşıllı üretim ve hizmet süreçlerinde meydana gelen dijitalleşme süreci, bilgi teknolojilerini etkin kullanan yüksek vasıflı iş gücüne olan talebi artırımıştır. Yüksek vasıflı iş gücüne artan talep, bilgi teknolojileri alanında eğitim veren kurumlara olan ihtiyacın da artmasına neden olmuştur (Nefiodow ve Nefiodow, 2014, s. 332).

Amerikan şirketleri, bilgi teknolojileri alanında meydana gelen yeniliklerin ortaya çıkmasında, öncü rol oynamışlardır (Modelski, 2006, s. 301). Bilgi teknolojileri alanı dışında faaliyet gösteren Amerikan şirketleri de, bilgi teknolojileri alanında meydana gelen yeniliklerden faydalanmışlardır. Bu şirketler, özellikle bin dokuz yüz doksanlı yıllarda bilgi teknolojileri alanında önemli yatırımlar yapmışlardır. Firmaların bilgi teknolojileri alanında yaptığı bu yatırımlar, önemli üretkenlik artışlarına yol açmıştır (Brynjolfsson ve Hitt, 2003, s. 806). Bilgi teknolojileri sektörü, kendi alanı dışında yarattığı üretkenlik artışının yanında, bin dokuz yüz doksanlı yıllarda ABD'de gerçekleşen büyüme sürecine önemli katkıda bulunmuştur. Bu durum, Avrupa Birliği ile karşılaştırmalı olarak, Grafik 1'de görülmektedir. Bilgi teknolojileri sektörünün $A B D$ 'de bin dokuz yüz doksanlı yıllarda gerçekleşen ekonomik büyüme sürecine katkısı yüzde otuzdan fazladır (Nefiodow ve Nefiodow, 2014, s. 332). 


\section{Grafik 1: Bilgi ve İletişim Teknolojileri Sektörlerinin Amerika Birleşik Devletleri ve Avrupa Birliğinde Ekonomik Büyüme Katkısı}

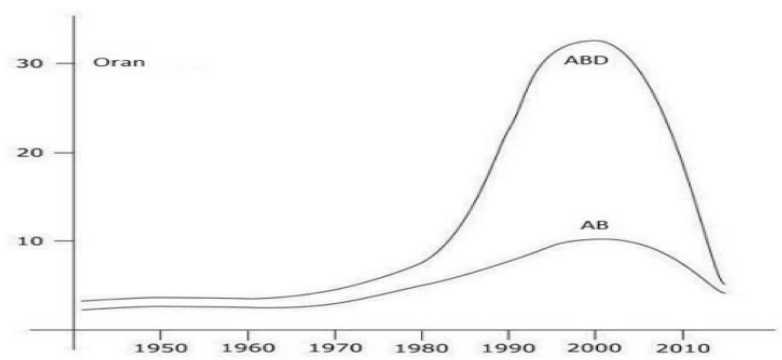

Kaynak: Nefiodow ve Nefiodow (2014).

Bilgi teknolojileri alanında ortaya çıkan yenilikler, bin dokuz yüz doksanlı yıllarda ABD ekonomisinde gerçekleşen büyüme sürecine önemli katkı yapmalarına rağmen; büyük gelişme dalgalarının kuruluş safhasında ortaya çıkan önemli sorunlara da neden olmuşlardır. İşsizlik, bir önceki bölümde de açıklandığı gibi, bu sorunların en önemlilerinden biridir. Beşinci Kondratieff Dalgası ile ortaya çıkan yeni teknoekonomi paradigması beraberinde üretim ve hizmet süreçlerinin giderek dijitalleşmesini, bilgisayarların ve internetin yaygın olarak kullanımını getirmiştir. Bilgi teknolojileri alanında meydana gelen gelişmeler, web tasarımı, yazılım geliştirme ve danışmanlık hizmetleri alanlarında yeni işler yaratmışlardır. Fakat bilgi teknolojileri alanında meydana gelen yeniliklerin ortadan kaldırdığı işler, yarattığı işlere göre çok daha fazladır (Collins, 2013, s. 52). Bu nedenle, Besinci Kondratieff Dalgası ile birlikte ortaya çıkan yeni teknoekonomi paradigmasının önemli özelliklerinden biri olan dijitalleşme süreci, işsizlik oranlarının artmasına neden olmuştur.

Dijitalleşme süreci ile beraber işsizlik oranlarının artması, özellikle Beşinci Kondratieff Dalgası'nın ortaya çıktığı ABD'de net olarak görülmektedir. ABD'de toplam istihdamın yüzde yetmiş beşini yaratan hizmet sektörü, bilgi teknolojileri alanında meydana gelen gelişmelerin etkisiyle istihdam kayıplarına uğramaktadır. Mağazalarda yapılan satış, yerini internetten yapılan alışverişlere bırakmaktadır. Yöneticilik pozisyonları, yapay zekânın gelişmesi ve ekonomide kullanımının yaygınlaşması ile birlikte azalmaktadır (Collins, 2013, s. 53). Bilgi teknolojileri alanında meydana gelen yenilikler, sadece ABD değil, başka ülkelerde de da ciddi istihdam kayıplarına neden olmaktadır (Brynjolfsson ve Mcafee, 2014, s. 170). 


\subsection{Beşinci Kondratieff Dalgasının Gelir ve Servet Dağılımına Etkisi}

Gelir dağılımı bozukluğu, daha önce gerçekleşen büyük gelişme dalgalarının kuruluş aşamasında görülmüştür. Gelir Dağılımı bozukluğu, Beşinci Kondratieff Dalgası'nın kuruluş aşamasında da ortaya çıkan önemli bir problemdir. Bu durum, Beşinci Kondratieff Dalgası'nın ortaya çıktığı ABD'de net olarak hissedilmektedir. ABD'de en tepede bulunan binde birlik en zengin kesimin ortalama yıllık geliri, I ki bin yedi yılında, en altta bulunan yüzde doksanlık kesimin ortalama gelirinin iki yüz yirmi katıdır. Benzer bir durum, servet dağılımı için de söz konusudur. En zengin yüzde birlik kesim, ABD'nin toplam zenginliğinin üçte birinden daha fazlasına sahiptir (Stiglitz, 2014. s. 43). Gelir ve servet eşitsizliğinde görülen bu eğilim, ABD'de iki bin sekiz yılında meydana gelen ve etkileri küresel olan kriz sonrasında da devam etmektedir. En tepede bulunan yüzde birlik kesim, liki bin on iki yılında, ABD'de toplam gelirin yüzde yirmi ikisini almaktadır (Brynjolfsson ve Mcafee, 2014, s. 153).

Gelir ve servet dağılımında görülen bozulma eğilimi, gelişmiş birçok ülkede görülmektedir. Gelir dağılımı bozukluğu, Almaya, İsveç ve Finlandiya gibi ülkelerde son otuz yılda ABD'den bile hızlı artmıştır. Vergi politikaları ve artan küresel rekabet gibi faktörler, gelir dağılımında meydana gelen bozulmaya önemli katkılar yapmışlardır. Fakat bilgi teknolojileri alanında meydana gelen gelişmeler, temel neden olarak öne çıkmaktadır (Brynjolfsson ve Mcafee, 2014, s. 158). Bilgi teknolojileri alanında ortaya çıkan yenilikler, yeni iş imkânları yaratmışlardır. Fakat bilgi teknolojileri alanında ortaya çıkan yeni işler, bilgi teknolojileri alanında meydana gelen gelişmelerin sonucu yok olan mesleklerdeki kadar yüksek ücret vermemektedirler (Collins, 2013, s. 52). Düşük vasıflı işlerde ücretlerin azalması ve yüksek vasıflı işlerde ise ücretlerin artması, bu sürece eşlik etmektedirler. Bilgi teknolojilerini etkin kullanan eğitim seviyesi yüksek kesim, bilgi teknolojilerinin kullanımının artması ile önemli ücret ve gelir kazanımları elde etmiştir. Dolayısıyla bilgi teknolojileri, yüksek vasıflı çalışanlar ve sermaye sahipleri ile düşük vasıflı işlerde çalışanlar arasındaki gelir eşitsizliğinin artmasında önemli rol oynamıştır (Brynjolfsson ve Mcafee, 2014, s. 158). 


\subsection{Beşinci Kondratieff Dalgasının Finansal Piyasalarda Yarattığı Değişimler}

Beşinci Kondratieff Dalgası ile birlikte ortaya çıkan ve daha önce gerçekleşen büyük gelişme dalgalarının kuruluş evresinde de görülen başka bir sorun, finans sektörü ile sanayi sektörü arasındaki bağların zayıflamasıdır. Bu durum, özellikle ABD'de, iki bin sekiz yılında başlayan küresel kriz öncesinde belirgin olarak görülmektedir. Finansal varlıkların küresel düzeyde anlık olarak alım satımı, bilgisayar sistemlerinde ve internet teknolojilerinde meydana gelen gelişmeler sayesinde mümkün hale gelmiştir (Perez, 2009b, s. 791-792). Bu gelişmeler, finans piyasalarının küresel olarak bütünleşmesine ve derinliğinin artmasına yol açmıştır (Reinhart ve Rogoff, 2010, s. 275). Finans piyasalarının küresel olarak bütünleşme sürecine, $A B D$ 'de finansal sistemi düzenleyen kanunların ve kurumların kaldırılması eşlik etmiştir. Bu çercevede, bin dokuz yüz doksan dokuz yılında kaldırılan GlassSteagall yasası özellikle önemlidir. Büyük Buhran sırasında çıkan yasa, tahvil ve hisse senedi satışına aracılık yapan yatııı bankaları ile mevduat toplayan ve kredi veren ticari bankaların faaliyetlerinin birbirinden ayrılmasını zorunlu hale getirmiştir. Yasanın kaldırılması ile ticari bankaların yatırım bankacılığı faaliyetlerinde bulunmalarının önü açılmıştır (Magdoff ve Yates, 2009, s. 80).

Finans sektörü, bilgi teknolojileri alanında meydana gelen gelişmelerden en çok faydalanan sektörlerin başında gelmektedir. Finans sektörü, ABD'de, bin dokuz yüz doksanlı yıllarda, ortaya çıkan yeni teknoekonomi paradigmasına başarıyla uyum sağlayarak; organizasyon, iletişim, müşterilere erişim gibi alanlarda önemli yeniliklere imza atmışır. Bilgi teknolojileri alanında faaliyet gösteren şirketlerin hızla büyümesi ve finansal piyasaları düzenleyen yasaların ve düzenlemelerin kaldırılması, bu sürece eşlik etmiştir. Bütün bu gelişmeler, bin dokuz yüz doksanlı yıllarda, bilgi teknolojileri alanında faaliyet gösteren şirketlerin hisse senedi fiyatlarının hızla artmasına ve bu durumun sonucu olarak hisse senedi fiyatlarının aşırı değerlenmesine neden olmuştur (Perez, 2009b, s. 782 - 783). Finansal varlıkların fiyatlarının hızla artması, hem sermaye sahipleri lehine gelir dağılımının hızla bozulmasına neden olmuş; hem de iki binli yılların başında aşırı değerlenen finansal varlıkların fiyatlarının hızla düşmesi ile ortaya çıkan finansal krize yol açmışıır. Bu süreç, ayrıca tasarruf sahiplerinin fiyatları hızla artan hisse senetleri gibi 
finansal varlıklara yatırım yapmasına neden olarak, yeni kurulan yenilikçi firmaların yatırımlarını finanse etmek için ihtiyaç duydukları fonlara ulaşımını zorlaştırmıştır.

ABD'de finansal piyasalarda yeni krizlerin oluşumunu önleyecek düzenlemeler, İki binli yılların başında NASDAQ'ın çöküşünün ardından yapılmamışır. Finansal yenilikler, yeterli finansal düzenlemelerin olmadığı bu ortamda, ekonomide öne çıkmaya başlamışlardır. Türev ürünler, bu yeni ortaya çıkan finansal yeniliklerin büyük kısmını oluşturmaktadırlar. Türev ürünlerin değeri, faiz oranı veya borsa endeksi gibi başka finansal varlıkların fiyatlarına dayanmaktadır. Bu karmaşık finansal ürünlerin getirisini ve riskini hesaplamak da oldukça zordur. Bin dokuz yüz seksenli yıllarda, gelirlerinin yüzde seksenini açtıkları kredilerden elde eden finansal kurumlar, Glass-Steagall yasasının kaldırılmasının etkisiyle, iki bin yedi yılında yılında gelirlerinin sadece yüzde elli sekizini açtıkları kredilerden elde etmeye başlamışlardır. Gelirlerinin geri kalan bölümü ise, çoğu türev niteliğindeki finansal varlıkların alış ve satış işlemlerinden kaynaklanmaktadır (Perez, 2009b, s. 782-783).

Türev ürünlerin fiyatlarının hızla artması ve bu durumun sonucu olarak finansal varlıkların fiyatlarının aşıı değerlenmesi, tasarruf sahiplerinin bu ürünlerin alınıp satıldığı piyasalara daha fazla yatırım yapmasına yol açmışır. Bu durum, finans sektörünün sanayi sektörlerinden bağımsız olarak hızla büyümesi sonucunu doğurmuştur. Türev ürünlerin fiyatlarının hızla değer kaybetmesi, iki bin sekiz yılında meydana gelen küresel finans krizinin temel nedenlerinden biri olmuştur.

Bilgi teknolojileri alanında meydana gelen yenilikler, iki bin sekiz yılında ve iki binli yılların başında, ABD'de oluşan krizlere neden olan finansal varlıkların fiyatlarının aşırı değerlenmesinde önemli rol oynamıştır (Perez, 2009b, s. 798). Finansal varlıkların fiyatlarının aşırı değerlenmesi, hem finans sektörü ile sanayi sektörü arasındaki bağların kopmasına neden olmuş, hem de ABD'de gittikçe bozulan gelir dağılımına önemli katkı yapmışırı. Finansal varlıkların fiyatlarının aşıı değerlenmesini takip eden finansal krizler, aynı zamanda büyük gelişme dalgasının kuruluş safhasının sonunun geldiğine de işaret etmektedirler. Fakat bu durum, büyük gelişme dalgasının yayılma safhasının otomatik olarak başlayacağı anlamına gelmemektedir. Her ne kadar oluşan koşullar, kuruluş safhasında ortaya çıkan 
sorunlara etkin çözümleri üretecek reformların gerçekleşmesi için uygun olsa da; bu noktada karar vericilerin tercihleri ön plana çıkmaktadır. Dolayısıyla finansal kriz sonrası süreç, büyümenin ve refahın altın çağına götürebileceği gibi, kuruluş safhasının biraz değişmiş hâli de olabilir (Perez, 2002, s. 52-53). Aşağıda bulunan Tablo 2'de, yukarıda açıklanan Beşinci Kondratieff Dalgasının yarattığı sosyoekonomik ve kurumsal değişimler özetlenmiştir.

Tablo 2: Beşinci Kondratieff Dalgasının Yarattığı Sosyoekonomik ve Kurumsal Değişimler

\begin{tabular}{|c|l|}
\hline Yeni Teknoloji & Bilgi ve iletişim teknolojileri \\
\hline İtici Sektörü & Bilgi teknolojileri sektörü \\
\hline Hâkim Organizasyon Tipi & Esnek üretim ve esnek organizasyon yapıları \\
\hline İş gücü Piyasalarında Yarattığı Değişimler & $\begin{array}{l}\text { Orta seviye vasıflara sahip olan iş gücüne talep } \\
\text { azalmıştır. Düşük ve yüksek Vasılara Sahip olan } \\
\text { iş gücüne talep artmıştır. Işsizlik oranlarında } \\
\text { artış meydana gelmiştir. }\end{array}$ \\
\hline Gelir ve Servet Dağııımına Etkisi & $\begin{array}{l}\text { Gelir ve Servet Dağıımı, bilgi ve iletişıim } \\
\text { teknolojilerinin etkisi ile bozulmuştur }\end{array}$ \\
\hline Finansal Piyasalarda Yarattığı Etkiler & $\begin{array}{l}\text { Finans sektörü ile sanayi sektörü arasında } \\
\text { bulunan bağlar zayıflamıştır. Finansal yenilikler, } \\
\text { yeterli kurumsal düzenlemeler olmadığından } \\
\text { krizlere neden olmuştur. }\end{array}$ \\
\hline
\end{tabular}

Kaynak: Tablo'daki bilgiler yazarlar tarafından hazırlanmıştır.

İssizlik, gelir dağılımı bozukluğu gibi sorunlar, içinde bulunduğumuz süreçte, başta Beşinci Kondratieff Dalgası'nın başladığı ABD olmak üzere gelişmiş ülkelerde devam etmektedir. ABD'de finansal piyasaları düzenlemek için, 2008 krizi sonrası dönemde, önemli girişimler vardır. Fakat bu gelişmeler, İkinci Dünya Savaşı sonrası dönemde olduğu gibi hızlı büyüme sürecine yol açmamıştır. Beşinci Kondratieff Dalgası'nın yayılma safhası, gelişmiş ülkelerde bilgi teknolojilerinin yarattığı değişimlerin etkisinin toplumun bütün katmanlarında hissedilmesi nedeniyle başlamıştır. Fakat kuruluş safhasında oluşan sosyoekonomik sorunlar devam etmektedir.

\section{Altıncı Kondratieff Dalgasının Yaratacağı Olası Sosyoekonomik ve Kurumsal Dönüşümler}

Altıncı Kondratieff Dalgası'nı başlatacağı düşünülen teknolojilerin önemli gelişmeler kaydetmesi, içinde bulunduğumuz süreçte meydana gelen önemli bir gelişmedir. Özellikle nanoteknoloji ve biyoteknoloji alanlarında meydana gelen ve 
gelecek yeniliklerin, Altıncı Kondratieff Dalgası'nı başlatacağı düşünülmektedir (Wilenius ve Casti, 2015, s. 340). Bilişsel bilimler alanında meydana gelecek gelişmelerin de, Altıncı Kondratieff Dalgası'nın başlamasında önemli rol oynaması beklenmektedir. Bu yeniliklerin hepsinin bilgi teknolojileri üzerine kurulu olacağı tahmin edilmektedir. Dolayısıyla bilgi teknolojileri, Altıncı Kondratieff Dalgası'nda da önemli rol oynamaya çok büyük olasılıkla devam edecektir (Akaev ve Rudskoi, 2017, s. 19).

\subsection{Altıncı Kondratieff Dalgasının Teknoloji ve Organizasyon Yapılarında Yaratacağı Olası Değişimler}

Illk Kondratieff Dalgası'nın başlamasına neden olan Sanayi Devrimi, tekstil sektörü gibi dar bir alanda oluşan sorunlara çözüm olarak ortaya çıkmıştır. Fakat bu alanda oluşan problemlere getirilen çözümler, makine üretimi için gerekli olan temel parçaların ortaya çıkmasına neden olmuştur. Bu yenilikler, teknoloji devrimine neden olmuş; ilk büyük gelişme dalgasını başlatmışlardır. Benzer bir durumun, Altıncı Kondratieff Dalgası için de söz konusu olacağı düşünülmektedir. Sağlık sektöründe meydana gelecek gelişmelerin diğer sektörleri de etkileyerek, Altıncı Kondratieff Dalgası'nın gelişmesine önemli katkı yapması beklenmektedir (Grinin, Korotayev ve Tausch, 2016, s. 158). Bu çercevede, sadece biyoteknoloji alanındaki gelişmelerin değil; nanoteknoloji alanındaki önemli gelişmelerin de sağlık sektöründe meydana gelmesi olasıdır (Grinin ve Grinin, 2015b, s. 47). Biyoçipler, bu duruma örnek olarak verilebilir. Bugün kalbin ritmini kontrol etmek için kullanılan biyoçiplerin gelecekte sağlık alanındaki kullanımının artması beklenmektedir (Grinin ve Grinin, 2015a, s. 134 -135). Başka sektörlerde meydana gelecek yeniliklerin sağlık sektörünü etkilemesi de oldukça muhtemeldir. Bugün 3D yazıcılar, uzay araçlarının özel parçalarının imalatında kullanılmaktadır. Yakın gelecekte 3D yazıcıların yapay organ üretimde yaygın olarak kullanılacağı tahmin edilmektedir. Bu gelişmelerin ardından kişiye özel ürünler üreten 3D endüstrilerinin oluşması da oldukça muhtemeldir (Akaev ve Rudskoi, 2017, s. 30).

Patent başvuru verileri, sağlık sektöründe meydana gelen ve gelecek yeniliklerin, Altıncı Kondratieff Dalgası'nın gelişmesine önemli katkı yapacağı 
görüşünü desteklemektedir. Vega-González, iki bin on yedi yılında yaptığı çalışmada, bin dokuz yüz doksan beş yılı ile iki bin on üç yılı arasında teknoloji alanında WIPO'ya yapılan patent başvurularını incelemiştir. Vega-González, teknoloji alanında yapılan patent başvurularını, uygulama alanlarını dikkate alarak beş gruba ayırmıştır. Daha sonra, bu beş grup için bin dokuz yüz doksan beş yılı ile iki bin on üç yılı arasında yapılan patent başvurularının ortalama yıllık büyüme oranlarını hesaplamıştır. Hesaplanan oranlar Grafik 2'de görülmektedir. Bu beş grup içinde en hızlı büyüyen alan, bilgi teknolojileri sektörüdür. Arkasından ise sağlık sektörü gelmektedir (Vega-González, 2017, s. 223-225). Bilgi teknolojileri sektöründe meydana gelen gelişmeler, sağlık sektörünü de önemli ölçüde etkilemektedir. Bu durum da dikkate alınırsa, sağlık sektöründe meydana gelen gelişmelerin bir sonraki dalga için ne kadar önemli olduğu ortaya çıkmaktadır.

Grafik 2: Patent Başvurularının Ortalama Yıllık Büyüme Oranı

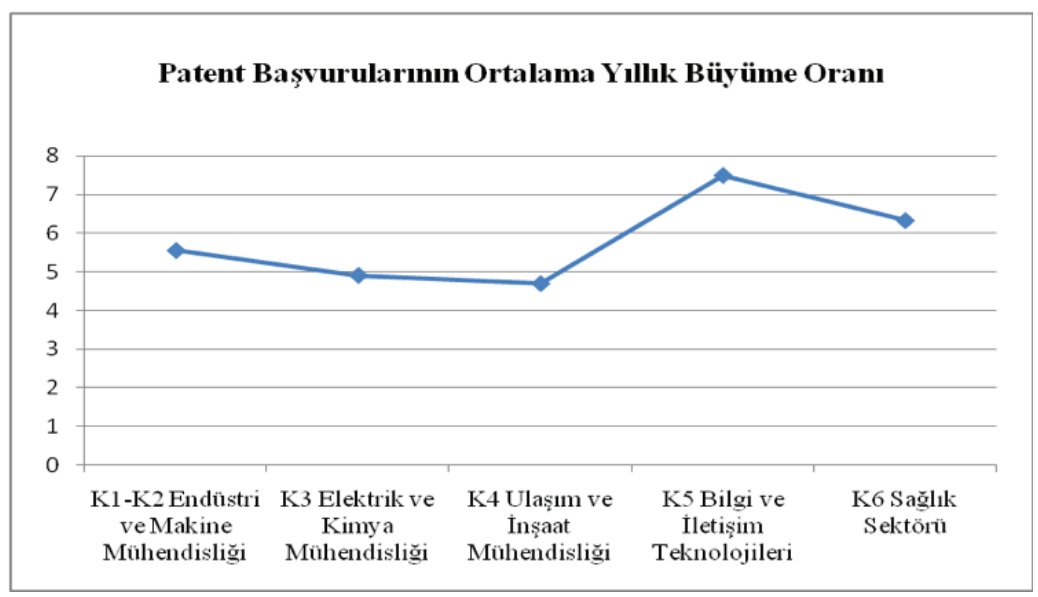

Kaynak: Vega-González (2017).

Nanoteknoloji, biyoteknoloji, bilişsel bilimler alanlarında meydana gelecek gelişmelerin, sağlık sektörü dışında da önemli değişimlere neden olması beklenmektedir. Nanoteknoloji alanında meydana gelen ve geleceği tahmin edilen yenilikler, bu duruma örnek olarak verilebilir. Nanoteknoloji alanında meydana gelen gelişmelerin birçok alanda uygulaması bulunmaktadır. Yeni malzemelerin imalatında ve geliştirilmesinde nanopartiküllerden yoğun olarak faydanılmaktadır. Gelecek dönemde nanopartiküllerin imalat sanayininde 
kullanımının daha da artması beklenmektedir. Otomobil endüstrisinde, karbon nonotüplerinden yoğun şekilde yararlanılmaktadır. Nanoteknoloji alanındaki gelişmeler ile yakından bağlantılı olan yakıt hücreleri ve yüksek performanslı piller, İmalat sanayinin çok farklı alanlarında kullanılmaktadırlar (Wonglimpiyarat, 2005, s. 1350). Bütün bu gelişmeler, hem ekonomide hem de imalat sanayininde önemli değişimler yaratacaklardır.

Nanoteknoloji, biyoteknoloji, bilişsel bilimler ve bilgi teknolojileri arasındaki yakınlaşmanın sonucu olarak ortaya çıkacak yenilikler; toplumu, bilimi ve ekonomiyi değiştirecek potansiyele sahiptir (Linstone, 2006, s. 266). Bu teknolojilerin bu özellikleri nedeniyle, Altıncı Kondratieff Dalgası'nı başlatacak teknoloji devrimine neden olacağı rahatıkla iddia edilebilmektedir. Her ne kadar Altıncı Kondratieff Dalgası'nın başladığı yönünde görüşler olsa da (Nefiodow ve Nefiodow, 2014, s. 327); Altıncı Kondratieff Dalgası'nın iki bin yirmili yıllarda başlaması daha olası görünmektedir (Grinin ve Grinin, 2015a, s. 135). Bu durumun nedeni, teknoloji devrimini başlatacak biyoteknoloji, nanoteknoloji ve bilişsel bilimler alanındaki yeniliklerin, gelişmiş ülkelerde ekonomik büyümenin motoru konumunda olmamasıdır. Buna rağmen gelişmiş ülkelerde bu alanlardaki yatıımlar hızla devam etmektedir. ABD, nanoteknoloji alanında yapılan araştırmaları desteklemek için kurduğu ulusal nanoteknoloji girişimine, iki bin ile iki bin on yılları arasında 13,5 milyar dolar kaynak aktarmıştır. ABD, yirminci yüzyılın ilk on yılında, nanoteknoloji, biyoteknoloji, bilişsel bilimler alanında yapılan araştırma geliştirme yatırımları için en çok finansal kaynak sağlayan ülkedir (Akaev ve Rudskoi, 2017, s. 27-28). Bu nedenle Altıncı Kondartieff Dalgası'nın ABD'de başlamasıı beklemek oldukça mantıkıdır.

Daha önce gerçekleşen teknoloji devrimleri, yeni teknoekonomi paradigmaları yaratmışlardır. Nanoteknoloji, biyoteknoloji ve bilişsel bilimlerde meydana gelecek yeniliklerin yaratacağı teknoloji devrimine de yeni bir teknoekonomi paradigmasının eşlik etmesi oldukça muhtemeldir. Ekonomideki mevcut maliyet yapılarını değiştirmeleri, teknoekonomi paradigmalarının en önemli özelliklerinden biridir. Mikroelektronik teknolojilerinin ucuzlaması, internet ile telekom altyapılarının her yere nüfuz etmesi, Beşinci Kondratieff Dalgası'nda hem üreticiler hem de tüketiciler için önemli pozitif dışsallıklar yaratmış ve önemli maliyet avantajları sağlamıştır 
(Freeman ve Perez, 1988, s. 60-61). Bu durum, bilgi teknolojilerinin üstünlügünün herkes tarafından kabul edilmesi sonucunu doğurarak, yeni teknoekonomi paradigmasının oluşmasında önemli rol oynamıştır. Nanoteknoloji ve biyoteknoloji alanında meydana gelecek yeniliklerin de benzer bir etkiyi yaratması olasıdır. Biyomalzemeler ile nanomalzemelerin yakın gelecekte yaygın olarak kullanılması beklenmektedir. Biyomalzemeler ve nanomalzemeler, şu an kullanılan malzemelere göre daha uzun ömürlüdür. Bu nedenle, biyomalzemeler ile nanomalzemelerin, inşaat ve ambalaj gibi birçok sektörde, şu anda kullanılan malzemelerin çoğunun yerini alması beklenmektedir. Biyomalzemeler ile nanomalzemelerin, kullanıldıkları sektörlerde maliyetlerin azalmasına neden olması oldukça muhtemeldir (Wilenius ve Casti, 2015, s. 340). Maliyetlerde meydana gelen bu azalma, yeni teknoloji paradigmasının toplumda yerleşmesine önemli katkı sağlayacaktır.

Küresel ısınmanın etkilerinin daha çok hissedilmesi ve çevreye zarar verecek gelişmelerin artması, yakın gelecekte beklenmektedir (Linstone, 2006, s. 267). Bu durum, büyük olasılıkla, insanların çevre sorunlarına olan duyarlılığının artmasına neden olacaktır (Dator, 2006, s. 315). Dolayısıyla ürün ile hizmet süreçlerinin tasarımında ve organizasyon yapılarının oluşturulmasında, çevre koşullarının daha çok dikkate alınmasını beklemek oldukça olasıdır. Biyomalzemeler ile nanomalzemeler, hem şu anda kullanılan ve çevre duyarlılığı az malzemelerin yerini alarak, hem de filtreleme teknolojileri gibi çevrenin korunmasına olanak sağlayan alanlarda ilerlemelere neden olarak (Wilenius ve Casti, 2015, s. 340), çevre kirliliğin azalmasına önemli katkılar yapacaklardır.

Çevre duyarlılığını temel alan dönüşümlerin enerji alanında da gerçekleşmesi beklenmektedir. Yenilenebilir enerji kaynakları, sağlık ve çevre koşulları açısından, yenilenemeyen enerji kaynaklarına göre önemli avantajlara sahiptir. Bu durum, yenilenebilir enerji kaynaklarının kullanılmasına yönelik baskının yakın gelecekte artmasına neden olacaktır; fakat dönüşümün yavaş olması beklenmektedir. Yenilenebilir enerji kaynaklarının birincil enerji kaynağı konumuna gelmesinin, şu andaki yenilenebilir enerjiye geçiş hızıyla, yirmi birinci yüzyılın sonlarında gerçekleşeceği tahmin edilmektedir (Thompson ve Zakhirova, 2017, s. 201). Fakat teknolojik değişimlerin hızlanması, bu süreci çabuklaştırabilir. 
Altıncı Kondratieff Dalgası'nın sağlık sektöründe meydan gelecek yeniliklerin sonucu olarak başlaması beklenmektedir. Bu nedenle, insanların fiziksel, psikolojik, ruhsal sorunlarını çözmek amacıyla geliştirilen teknolojilerin, Altıncı Kondratieff Dalgası'nı başlatacağı tahmin edilmektedir. Dolayısıyla insanların sağlık sorunlarına çözüm getiren teknolojiler, tarihte ilk defa, sosyal ve ekonomik gelişmenin kaynağı olan teknoloji devrimine neden olacaktır (Nefiodow ve Nefiodow, 2014, s. 351). Altıncı Kondratieff Dalgası ile oluşacak yeni teknoekonomi paradigmasının önemli özelliklerinden birinin insan odaklılık olması oldukça muhtemeldir. İnsan sağlığı ve ihtiyaçları, ürün ve hizmet süreçlerinin tasarımında ve organizasyon yapılarının oluşturulmasında, daha çok dikkate alınacaktır.

Küreselleşme, Beşinci Kondratieff Dalgası'nda ortaya çıkan teknoekonomi paradigmasının önemli özelliklerden biridir. Küreselleşme sürecinin Altıncı Kondratieff Dalgası'nda da etkisini sürdürmesi beklenmektedir (Wilenius ve Casti, 2015, s. 340). Dolayısıyla küreselleşme süreci, Altıncı Kondratieff Dalgası ile oluşacak yeni teknoekonomi paradigmasının önemli özelliklerinden biri olacaktır. Yeni teknoekonomi paradigması ile nanoteknoloji ve biyoteknoloji alanlarında meydana gelecek yeniliklerin, yeni organizasyon biçimleri ortaya çıkarması olasıdır.

Çevre duyarlılığının Altıncı Kondratieff Dalgası'nın teknoekonomi paradigmasının şekillenmesinde önemli rol oynayacağı düşünülmektedir. Bu çercevede, firmaların, yeni teknolojilerin gereksinimlerine göre organizasyon yapılarını oluştururken, sürdürebilirliği daha çok dikkate almaları beklenmektedir. Sürdürebilirliğe önem veren firmalar, kendilerinin ekonomik yararı kadar, sosyal ve çevresel faydaları dikkate alacaklardır. Bu durumun sonucu olarak, bu firmalar, daha etkin süreçler geliştirerek maliyetlerini önemli ölçüde azaltacaklardır. Ayrıca kaynakların etkin kullanımı, bu firmalara önemli rekabet avantajı da sağlayacaktır (Silva ve Di Serio, 2016, s. 130-131).

Büyük gelişme dalgalarının kuruluş safhası, daha önce, teknoloji devrimlerinin ardından başlamıştır. Nanoteknoloji ve biyoteknoloji alanındaki gelişmelerin sonucu olarak ortaya çıkması beklenen teknoloji devriminin, iki bin yirmili yıllarda, yeni büyük gelişme dalgasının kuruluş safhasını başlatması oldukça 
olasıdır. Daha önce gerçekleşen büyük gelişme dalgalarının kuruluş safhasında görülen sorunlar, Altıncı Kondratieff Dalgası'nın başlaması ile tekrar gündeme gelebilir. Bu durum, biyoteknoloji, nanoteknoloji ve bilgi teknolojilerinin yakınlaşması sonucu ortaya çıkacak muhtemel teknolojik değişimler dikkate alındığında oldukça olasıdır.

\subsection{Altıncı Kondratieff Dalgasının İş Piyasaları, Finans Piyasaları ve Servet ve Gelir Dalığımı Üzerinde Yaratacağı Olası Değişimler}

Akıllı sistemlerin ve robotların, Altıncı Kondratieff Dalgası'nın başlamasının beklendiği sağlık sektöründe, yakın gelecekte daha çok kullanılması beklenmektedir. Bu durum, doktorların yaptığı işlerin bir kısmının, robotlar ve akıllı sistemler tarafından yapılmasına neden olacaktır. Doktorluk mesleğinin yakın gelecekte devam etmesi beklenmektedir. Fakat doktorların sayısında, büyük ihtimalle, artış meydana gelmeyecektir. Bu durum, Altıncı Kondratieff Dalgası́nın lokomotif sektörü olması beklenen sağlık alanında bile yeni istihdam yaratılamayacağı anlamına gelmektedir (Grinin ve Grinin, 2015b, s. 47). Nanoteknoloji, biyoteknoloji ve bilgi teknolojilerinin yakınlaşması sonucu ortaya çıkacak yeni sektörlerin de çok fazla yeni istihdam yaratması beklenmemektedir. Akaev ve Rudskoi yaptıkları çalışmada, iki bin kırk ile iki bin kırk beş arasında, bu sektörlerin, yedi milyonu ABD'de olmak üzere toplam on sekiz milyon kişiye yeni iş imkânı yaratacağını tahmin etmektedirler. Bu sayı, dünya nüfus artış eğilimleri göz önüne alındığında oldukça küçüktür (Akaev ve Rudskoi, 2017, s. 28). Bu nedenle, Altıncı Kondratieff Dalgası'nın başlamasının, gelişmiş ülkelerde işsizlik sorununu beraberinde getirmesi oldukça olasıdır.

Gelir dağılımı bozukluğu, Altıncı Kondratieff Dalgasının başlaması ile ortaya çıkması beklenen diğer bir sorundur. Nanoteknoloji, biyoteknoloji ve bilgi teknolojilerinin yakınlaşması sonucu ortaya çıkacak sektörlerin çok fazla yeni iş imkânı yaratmayacağı tahmin edilmektedir. Bu sektörlerde çalışanların yüksek vasıflara sahip olmaları nedeniyle, düşük vasıflara sahip olan çalışanlara göre daha yüksek ücret almaları beklenmektedir. Bu gibi faktörlerin, gelişmiş ülkelerdeki gelir dağılımı bozukluğunu arttırması oldukça olasıdır. 
Altıncı Kondratieff Dalgası'nın başlaması, daha önce gerçekleşen büyük gelişme dalgalarının kuruluş safhasında görülen, finans sektörü ile sanayi sektörü arasındaki bağların kopması sorununu da gündeme getirebilir. Birçok yeni şirket, yeni sektörlerin ortaya çıkması ile beraber kurulmaktadır. Biyoteknoloji, bu duruma örnek olarak verilebilir. İki bin sekiz yılında, yüzde seksen dördü ABD ve Avrupa'da faaliyet gösteren dört bin yedi yüz biyoteknoloji şirketi vardır. Biyoteknolojinin tarım, tekstil, kozmetik gibi birçok alanla bağlantılı olması, bu firmaların yüksek karlar elde etme olasılığını arttırmaktadır (Nefiodow ve Nefiodow, 2014, s. 342). Biyoteknoloji alanında faaliyet gösteren firmaların sayıının, gelecekte daha çok artması oldukça muhtemeldir. Altıncı Kondratieff Dalgası'nın başlaması ile beraber bu firmaların hisse senetlerinin hızla değerlenmesi, sahip oldukları gelişme ve kâr potansiyeli nedeniyle oldukça olasıdır. Benzer bir durum, Altıncı Kondratieff Dalgasında etkili olacak diğer sektörler için de söz konusudur. Bu nedenle, hisse senedi fiyatlarında görülen hızlı artışlar, daha önce gerçekleşen Kondratieff Dalgalarında olduğu gibi, sonu kriz ile biten finansal varlıkların fiyatlarının aşırı değerlenmesine ve finans sektörü ile sanayi sektörü arasındaki bağların zayıflamasına neden olabilir.

Başta ABD olmak üzere gelişmiş ülkeler, Beşinci Kondratieff Dalgası'nın yayılma safhasında bulunmaktadırlar. Teknoloji devrimine neden olan teknolojiler, bundan önce gerçekleşen dört büyük gelişme dalgasının yayılma safhasının sonunda, teknoloji devriminin başladığı ülkelerde doygunluğa ulaşmışlardır. Doygunluğa ulaşma sürecine, bu teknolojilerin az gelişmiş ülkelere transfer edilmesi süreci eşlik etmiştir (Perez, 2002, s. 64). Bu durum nedeniyle, bilgi teknolojilerinin etkilerinin gelişmekte olan ülkelerde daha çok hissedilmesi, içinde bulunduğumuz süreçte ve gelecek dönemde, oldukça muhtemeldir. Beşinci Kondratieff Dalgası'nın gelişmekte olan ülkelerde başlaması, büyük gelişme dalgalarının kuruluş safhasında görülen işsizlik, gelir dağılımı bozukluğu, finans sektörü ile sanayi sektörü arasındaki bağların zayıflaması gibi sorunların gelişmekte olan ülkelerde de görülmesine yol açabilir. Birçok gelişmekte olan ülkede bu sorunların hâlihazırda mevcut olması, bu problemlerin daha çok ağırlaşmasına neden olacaktır.

Aşağıda bulunan Tablo 3, yukarıda açıklanan Altıncı Kondrateff Dalgasının yaratacağı olası sosyoekonomik ve kurumsal değişimleri özetlemektedir. 
Tablo 3: Altıncı Kondratieff Dalgasının Yaratacağı Olası Sosyoekonomik ve Kurumsal Değişimler

\begin{tabular}{|c|l|}
\hline Yeni Teknoloji & Nanoteknoloji, biyoteknoloji ve bilişsel bilimler \\
\hline İtici Sektörü & Sağlık sektörü \\
\hline Hâkim Organizasyon Tipi & $\begin{array}{l}\text { Insan sağlığı ve ihtiyaçları, ürün ve } \\
\text { hizmetlerinin süreçlerinin tasarımında ve } \\
\text { organizasyon yapılarının oluşturulmasında } \\
\text { daha çok dikkate alınacaktır. Çevre duyarlılı̆ı } \\
\text { ve sürdürebilirlik, firmalar açısından önemli } \\
\text { olacaktır. }\end{array}$ \\
\hline İş gücü Piyasalarında Yaratacağı Olası & $\begin{array}{l}\text { Yeni teknolojilerin etkisi ile işsizlik oranlarının } \\
\text { artması oldukça muhtemeldir. }\end{array}$ \\
\hline Geğişimler & $\begin{array}{l}\text { Gelir dağılımı bozukluğunu arttırması oldukça } \\
\text { olasıdır. }\end{array}$ \\
\hline Finansal Piyasalarda Yaratacağı Muhtemel & $\begin{array}{l}\text { Finans sektörü ile sanayi sektörü arasındaki } \\
\text { bağların kopmasını tekrar gündeme getirebilir. } \\
\text { Etkiler }\end{array}$ \\
& $\begin{array}{l}\text { Yeni teknolojiler ve yeni şirketler, finansal } \\
\text { varlıkların fiyatlarının aşırı değerlenmesine } \\
\text { neden olabilir }\end{array}$ \\
\hline
\end{tabular}

Kaynak: Tablodaki bilgiler yazarlar tarafından hazırlanmıştır.

Bilgi teknolojilerinin etkilerinin gelişmekte olan ülkelerde yayılmaya başlaması ve gelişmiş ülkelerin nanoteknoloji ile biyoteknoloji alanında önemli gelişmeler kaydetmesi, beraberinde yakalama sorununu gündeme getirecektir. Bilgi teknolojilerine yeterli önemi vermeyen gelişmekte olan ülkelerin, hem gelişmiş ülkeleri, hem de bilgi teknolojileri alanında önemli yatırımlar yapan gelişmekte olan ülkeleri yakalaması oldukça zorlaşacaktır. Dolayısıyla gelişmekte olan ülkeler, büyük gelişme dalgalarının kuruluş safhasında görülen problemlerin yanında, teknoloji olarak daha ileri düzeyde bulunan ülkeleri yakalama sorunu ile de karşı karşıyadırlar.

\section{Sonuç}

Kapitalist ekonomiler, sanayi devriminden sonra, hızlı büyüme sürecine girmişlerdir. Fakat bu büyüme süreci kesintisiz değildir. Genellikle hızlı genişleme dönemlerinin ardından, toplumun geniş kesimlerini etkileyen kriz dönemleri gelmektedir. Kapitalist gelişme sürecinde görülen elli veya altmış yıllık bu dalgalanmalar, ilk defa Rus iktisatçı Kondratieff tarafından gözlemlenmiş, Schumpeter tarafından açıklanmıştır. Schumpeter, geliştirdiği iş çevrimi teorisinde, 
uzun dalgaların toplumda ve kurumlarda meydana getirdiği değişimleri detaylı olarak açıklayamamıştır. Carlota Perez, geliştirdiği büyük gelişme dalgası yaklaşımı ile boşluğu doldurmaya çalışmıştır.

Perez, teknoloji devrimlerinin, büyük gelişme dalgalarının başlamasına neden olduğunu iddia etmektedir. Büyük gelişme dalgası, kendi içinde kuruluş safhası ve yayılma safhası olarak adlandırılan iki evreye ayrılmaktadır. Bu iki evre arasında ise geçiş safhası bulunmaktadır. Yeni teknolojiler ve yeni teknoekonomi paradigması, kuruluş safhasında, toplumun bütün alanlarına hızla yayılmaktadır. İşsizlik, gelir dağılımı bozukluğu ve finans sektörü ile sanayi sektörü arasında bulunan bağların kopması gibi sorunlar, bu evrede ortaya çıkmaktadırlar. Finansal varlıkların fiyatlarının aşırı artması ve daha sonra hızla düşmesi sonucu oluşan finansal kriz, kuruluş safhasını sona erdirmektedir. Finansal kriz sonrası dönemde ekonomi, süresi belirsiz olan durgunluk sürecine girmektedir. Kuruluş safhasında ortaya çıkan toplumsal gerilimler, bu geçiş safhasında, daha fazla görünür hale gelmektedir. Bu nedenle, kurumsal reform ihtiyacı artmaktadır. Büyük gelişme dalgasının yayılma safhası, kurumsal reformların yapılmaya başlaması ile başlamaktadır. Yeni teknoekonomi paradigması, bu evrede, toplumun bütün alanlarına yayılmaktadır. Kuruluş evresinde oluşan sorunlar, yapılan kurumsal reformlar sonucunda çözüme kavuşmaktadır. Büyük gelişme dalgası, başlamasına neden olan teknolojilerin doygunluğa ulaşması ile sona ermektedir.

Bilgi teknolojileri alanında meydana gelen yenilikler, bin dokuz yüz yetmişli yıllarda, Beşinci Kondratieff Dalgası'nın ABD'de başlamasına neden olmuştur. Yeni teknoekonomi paradigması, toplumda hızla yayılmaya başlamıştır. Fakat bu durum, başta Beşinci Kondratieff Dalgası'nın başladığı ABD olmak üzere gelişmiş ülkelerde, büyük gelişme dalgalarının kuruluş evresinde görülen sorunlara neden olmuştur. ABD'de iki bin sekiz yılında başlayan küresel finans krizi, Beşinci Kondratieff Dalgası'nın kuruluş safhasının sonunun geldiğine işaret etmektedir. Bilgi teknolojilerinin yarattığı değişimlerin etkisi, lçinde bulunduğumuz süreçte, gelişmiş ülkelerde, toplumun bütün katmanlarında hissedilmektedir. Bu nedenle, Beşinci Kondratieff Dalgası'nın yayılma safhası başlamış olmasına rağmen; büyük gelişme dalgasının kuruluş safhasında oluşan sorunlar halen devam etmektedir. 
Nanoteknoloji ve biyoteknoloji alanındaki ilerlemelerin sonucu olarak ortaya çıkması beklenen teknoloji devriminin, iki bin yirmili yıllarda, yeni büyük gelişme dalgasının kuruluş safhasını başlatması oldukça olasıdır. Altıncı Kondratieff Dalgası'nın başlaması, daha önce gerçekleşen büyük gelişme dalgalarının kuruluş safhasında görülen işsizlik, gelir dağılımı bozukluğu ve finans sektörü ile sanayi sektörü arasında bulunan bağların kopması gibi sorunları tekrar gündeme getirebilir. Bu sorunlar, gelişmekte olan ülkelerde hala devam etmektedir. Yakın gelecekte Altıncı Kondratieff Dalgası'nın gelişmekte olan ülkelerde başlaması, bu problemleri daha da ağırlaştırabilir.

Teknoloji devrimine yol açan teknolojiler, bundan önce gerçekleşen dört büyük gelişme dalgasının yayılma safhasının sonunda, teknoloji devriminin başladığı ülkelerde doygunluğa ulaşmışlardır. Büyük gelişme dalgasına neden olan teknolojiler, doygunluğa ulaşma süreci ile birlikte, az gelişmiş ülkelere transfer edilmiştir. Bu durum nedeniyle, bilgi teknolojilerinin etkilerinin gelişmekte olan ülkelerde daha çok hissedilmesi, içinde bulunduğumuz süreçte ve gelecek dönemde oldukça olasıdır. Gelişmekte olan ülkelerde Beşinci Kondratieff Dalgası'nın başlaması, büyük gelişme dalgalarının kuruluş safhasında görülen sorunlara neden olabilir. Mevcut durumda birçok gelişmekte olan ülkenin bu sorunlar ile karşı karşıya olması, problemleri daha da ağırlaştıracaktır.

İssizlik, gelir dağılımı bozukluğu ve finans sektörü ile sanayi sektörü arasında bulunan bağların kopması gibi sorunlar, hem gelişmiş, hem de gelişmekte olan ülkelerde mevcuttur. Gelişmekte olan ülkelerde Beşinci Kondratieff Dalgası'nın, gelişmiş ülkelerde ise Altıncı Kondratieff Dalgası'nın başlaması, bu problemleri daha da ağırlaştıracaktır. Gelişmekte olan ülkeler, bu problemlerin yanında, bilgi teknolojileri, nanoteknoloji ve biyoteknoloji alanındaki gelişmeleri yurt dışından transfer etmek ve kendi kaynakları ile geliştirmek sorunları ile de karşı karşıyadırlar. Hem gelişmiş, hem de gelişmekte olan ülkelerin bu problemlerin üstesinden gelmeleri için ulusal yenilik sistemlerini geliştirmeleri ve Altıncı ile Besinci Kondartieff Dalgaları'nın dayandığı teknolojilerin ihtiyaçlarına göre yeniden düzenlemeleri gerekmektedir. 
Ulusal yenilik sistemi, yeni teknolojilerin gelişimine ve yayılmasına katkı yapan kurumların ve organizasyonların kümesi olarak tanımlanabilir. Eğitim kurumları, finansal kurumlar, üniversiteler, teknoloji politikalarını düzenleyen ve denetleyen kamu kurumları, ulusal yenilik sisteminin içinde yer almaktadırlar. Altıncı ve Beşinci Kondratieff Dalgaları'nın dayandığı teknolojileri geliştirebilen ve kullanılabilen vasıflı çalışan ihtiyacı gelecek dönemde artacaktır. Hem gelişmiş, hem de gelişmekte olan ülkelerin, eğitim sistemlerini ve üniversitelerini, bu nitelikli çalışan ihtiyacını karşılayacak şekilde yeniden düzenlemeleri gerekmekedir. Altıncı ve Beşinci Kondratieff Dalgaları, yeni endüstriler ortaya çıkartacaklardır. Hem gelişmiş, hem de gelişmekte olan ülkelerde bulunan finansal kurumlar, bu yeni endüstrilerin ihtiyaç duyduğu fonları sağlamak istemeyebilirler. Bu nedenle, hem gelişmiş, hem de gelişmekte olan ülkelerde finansal sistemin, bu endüstrilerin ihtiyaç duyduğu fonları sağlayacak şekilde yeniden düzenlenmesi oldukça önemlidir. Hem gelişmiş, hem de gelişmekte olan ülkelerde kamu kurumlarının, yeni teknolojilerin ihtiyaç duyduğu alt yapıları oluşturmaları gerekmektedir.

Hem gelişmiş, hem de gelişmekte olan ülkelerde, ulusal yenilik sistemlerinin Altıncı ve Besinci Kondartieff Dalgaları'nın dayandığı teknolojilerin ihtiyaçlarına göre yeniden düzenlemesi, Altıncı ve Besinci Kondratieff Dalgaları'nın başlaması nedeniyle oluşan ve oluşacak sorunları azalatacaktır.

Teşekkür: Yazarlar, makalenin yayına hazırlık aşamasında vermiş olduğu desteklerden ötürü Dr. Kemal Dinçer Dingeç'e, Dr. Emine Tahsin'e, Mehmet Ali Tüysüzoğlu ve Mustafa Dönmez'e teşekkür ederler.

Finansal Destek: Yazarlar bu çalışma için finansal destek almamışlardır.

\section{Kaynakça}

Aghion, P., \& Howitt, P. (1992). A model of growth through creative destruction. Econometrica, 60(2), 323-351. DOi: 10.2307/2951599

Akaev, A., \& Rudskoi, A. (2017). The potential of breakthrough techologies and its social consequences. In T. Devezas, J. Leitao \& A. Sargygulov (Eds.), Industry 4,0 entrepreneurship and structural change in the new digital landscape (pp. 13-41). Switzerland: Springer. 
Brynjolfsson, E., \& Hitt, L. (2003). Computing productivity: firm level evidence. The Review of Economics and Statistics, 85(4), 793-808. https://doi.org/10.1162/003465303772815736

Brynjolfsson, E., \& Mcafee, A. (2014). Second machine age (L. Göktem, Çev.). İstanbul: Türk Hava Yolları Yayınları.

Clark, G. (2013). Fukaralığa veda dünyanın kısa iktisadi tarihi (E. Demircioğlu, Çev.). İstanbul: İstanbul Bilgi Üniverisitesi Yayınları.

Collins, R. (2013). Orta sınıf işlerin sonu: Artık kaçış yok. R. Collins, M. Mann, M. Derluguian, C. Calhoun (Ed.), Kapitalizmin geleceği var mı? (B. Doğan, Çev.), içinde (s. 48-84). İstanbul: Metis Kitap.

Dator, J. (2006). Alternative Futures for K - Waves. In T. Devezas (Eds.), Kondratieff Waves Warfare And World Security (pp. 311-317). Amsterdam: Pinter IOS Press.

Dosi, G. (1982). Techological paradigms and technological trajectories. Research Policy, 11, 147-162. https://doi.org/10.1016/0048-7333(82)90016-6

Dosi, G., \& Labini, M. (2007). Technological paradigms and trajectories. In H. Hanusch \& H. Pyka (Eds.), Elgar companion to Neo-Schumpeterian economics (pp. 331-359). USA: Edward Elgar.

Dosi, G., \& Nelson, R. (2010). Technical change and industrial dynamics as evolutionary processes. In K. Arrow \& M. Intriligator (Eds.), Handbook in economics (pp. 51-127). Netherlands: North Holland.

Dosi, G., \& Nelson, R. (2013). The evolution of technologies: an assassment of the state of the state of the art. Eurasian Business Review, 3(1), 3-46. https://doi.org/10.14208/BF03353816

Freeman, M. (1987). Technical innovation, diffusion, and long cycles of economic development. In T. Vasko (Eds.), The long wave debate (pp. 295-309). Berlin: Spinger - Verlag.

Freeman, M. (1994). The economics of technical change. Cambridge Journal of Economics, 18(5), 463-514. https://doi.org/10.1093/oxfordjournals.cje.a035286

Freeman, M., \& Perez, C. (1988). Structural crises of adjustment, business cycles and investment behaviour. In G. Dosi (Eds.), Techical change and economic theory (pp. 38-66). London: Pinter Publishers.

Grinin, A., \& Grinin, L. (2015a). Global techological perspectives in the light of cybernetic revolution and theory of long cycles. Journal of Globalization Studies, 6(2), 119-142. Erişim Adresi: https:// www.sociostudies.org/journal/articles/396111/

Grinin, A., \& Grinin, L. (2015b). The cybernetic revolution and historical process. In L. Grinin, I. Ilyin, P. Herrmann, A. Korotayev (Eds.), Globalistics And Globalization Studies (pp. 15-57). Volgograd: Uchitel Publishing House.

Grinin, L., Korotayev, A., \& Tausch, A. (2016). Economic cycles, crises, and the global periphery. Switzerland: Springer.

Hirooka, M. (2005). Nonlinear dynamism of innovation and business cycle, entrepreneurship. In E. Cantar, E. Dinopoulos, R. Lanzilotti (Eds.), The new economy and public policy, Schumpeter perspectives (pp. 289-316). Germany: Springer. 
Hirooka, M. (2006). Complexity in discrete innovation systems. ECO, 8(2), 20-34. doi: 10. emerg/10.17357.d8cf2da38bebf8d00ec24a23ebdb3758.

Kleinknecht, A., \& Van Der Panne, G. (2006). Who was right? Kuznets in 1930 or Schumpeter in 1939. In T. Devezas (Eds.), Kondratieff waves warfare and world security (pp. 118-125). Amsterdam: Pinter IOS Press.

Landes, D. (2017). Milletlerin zenginliği ve yoksulluğu (A. Doğru, Çev.). İstanbul: Feylesof Kitap.

Lauça, F. (2007). Long waves, the pulsation of modern capitalism. In H. Hanusch, A. Pyka (Eds.), Elgar companion to Neo-Schumpeterian economics (pp. 766-774). USA: Edward Elgar.

Linstone, H. (2006).The information and molecular ages: will k-waves persist? In T. Devezas (Eds.), Kondratieff waves warfare and world security (pp. 260-269). Amsterdam: Pinter IOS Press.

Lucas, R. (2004). The industrial revolution: past and future. Economic Education Bulletin, XLIV(8), 1-8. Erişim Adesi: https://www.aier.org/research/industrial-revolution-past-and-future

Magdoff, F. ve Yates, M. (2009). Ekonomik krizin ABC'si (A. Kırmızıgül, Çev.). İstanbul: Epos Yayınları.

Modelski, G. (2006). Global political evolution, long cycles, and k - waves. In T. Devezas (Eds.), Kondratieff waves warfare and world security (pp. 293-302). Amsterdam: Pinter IOS Press.

Nefiodow, L., \& Nefiodow, S. (2014). The Six Kondratieff. The growth engine of the 21st century. In L. Grinin, T. Devezas, A. Korotayev (Eds.), Kondratieff waves Juglar - Kuznets - Kondratieff (pp. 326-352). Volvograd: Uchitel Publishing House.

Nelson, R. (2008). What enables rapid economic progress: What are the needed institutions. Research Policy, 37, 1-11. https://doi.org/10.1016/j.respol.2007.10.008

Papenhausen, C. (2008). Causal mechanisms of long waves. Futures, 40, 788-794. https://doi. org/10.1016/j.futures.2008.07.010

Perez, C. (1983). Structural change and assimilation of new technologies in the economic and social systems. Futures, 15(5), 357-375. https://doi.org/10.1016/0016-3287(83)90050-2

Perez, C. (1985). Microelectronics, long waves and world structural change: new perspectives for developing countries. World Development, 13(3), 441-463. https://doi.org/10.1016/0305750X(85)90140-8

Perez, C. (2002). Techological revolutions and financial capital, UK: Edward Edgar.

Perez, C. (2007). Finance and technical change: A long term view. In H. Hanusch \& H. Pyka (Eds.), Elgar companion to Neo-Schumpeterian economics (pp. 775-799). USA: Edward Elgar.

Perez, C. (2009a). Techological revolution and techo-economic paradigms. Working Papers in Techology Govarnance and Economic Dynamics, 20, 1-24. https://ideas.repec.org/p/tth/ wpaper/20.html

Perez, C. (2009b). The double buble at the turn of the century: technological roots and structural implications. Cambridge Journal of Economics, 33, 779-805. https://doi.org/10.1093/cje/bep028

Perez, C. (2010). The financial crisis and the future of innovation: a new of technical change with the aid of history. Working Papers in Techology Govarnance and Economic Dynamics, 28, 1-42. https://ideas.repec.org/p/tth/wpaper/28.html 
Perez, C. (2014). A new age of technological progress. In C. Umunna (Eds.), Owing The Future (pp. 19-31). London: Policy Network.

Reinhart, C. ve Rogoff, K. (2010). Bu defa farklı (L. Konyar, Çev.). İstanbul: NTV Yayınları.

Rosenberg, N., \& Frischtak, C. (1984). Technological innovation and long waves. Cambridge Journal of Economics, 8, 7-24. https://doi.org/10.1093/oxfordjournals.cje.a035536

Silva, G., \& Di Serio, L. (2016). The sixth wave of innovation: are we ready?, Al Revista de Administração e Inovação, 13(2), 128-134. https://doi.org/10.1016/j.rai.2016.03.005

Silverberg, G. (2007). Long waves: conceptual, empirical and modelling issues. In H. Hanusch \& H. Pyka (Eds.), Elgar companion to Neo-Schumpeterian economics (pp. 800 - 819). USA: Edward Elgar.

Silverberg, G., \& Verspagen, B. (2003). Breaking the waves: a Poisson regression approach to Schumpeterian clustering of basic innovations, Cambridge Journal of Economics, 27, 671-693. https://doi.org/10.1093/cje/27.5.671

Stiglitz, J. (2014). Eşitsizliğin bedeli (O. İşler, Çev.). İstanbul: İletişim Yayınları.

Thompson, W., \& Zakhirova, L. (2017). Racing to a renewable transition? In T. Devezas, J. Leitao, A. Sargygulov (Eds.), Industry 4,0 entrepreneurship and structural change in the new digital landscape (pp. 183-203). Switzerland: Springer.

Vega-González, L. R. (2017). Using patents and innovation strings to anticipate the next Kondratieff long waves. International Journal of Technology Intelligence and Planning, 11(3), 212-219. DOi: 10.1504/IJTIP.2017.10006430

Wilenius, M., \& Casti, J. (2015). Seizing the X-events. The six K-wave and the shocks that may upend it. Techological Forecasting \& Social Change, 94, 335-349. http://dx.doi.org/10.1016/j. techfore.2014.12.003

Wonglimpiyarat, J. (2005). The nano-revolution of Schumpeter's Kondratieff cycle. Technovation, 25(11), 1349-1354. https://doi.org/10.1016/j.technovation.2004.07.002 
